\title{
Coupled Climate-Economy-Biosphere (CoCEB) model - Part 1: Abatement efficacy of low-carbon technologies
}

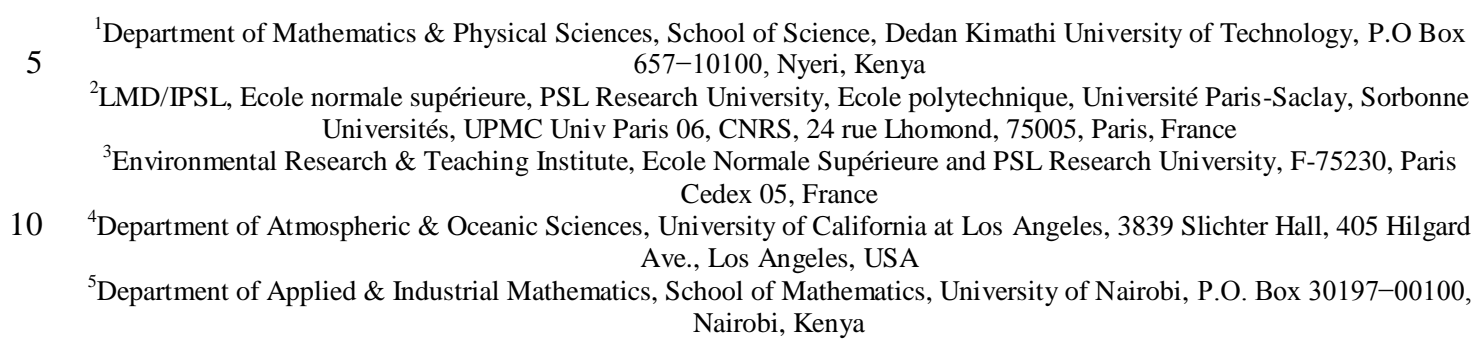

${ }^{2}$ LMD/IPSL, Ecole normale supérieure, PSL Research University, Ecole polytechnique, Université Paris-Saclay, Sorbonne Universités, UPMC Univ Paris 06, CNRS, 24 rue Lhomond, 75005, Paris, France

${ }^{3}$ Environmental Research \& Teaching Institute, Ecole Normale Supérieure and PSL Research University, F-75230, Paris Cedex 05, France

$10{ }^{4}$ Department of Atmospheric \& Oceanic Sciences, University of California at Los Angeles, 3839 Slichter Hall, 405 Hilgard Ave., Los Angeles, USA

${ }^{5}$ Department of Applied \& Industrial Mathematics, School of Mathematics, University of Nairobi, P.O. Box 30197-00100, Nairobi, Kenya

Correspondence to: K. B. Z. Ogutu (okeroboto@gmail.com)

15 Abstract. In the present Part 1 of a two-part paper, we formulate and study a simple Coupled Climate-Economy-Biosphere (CoCEB) model. This highly idealized model constitutes the basis of our integrated assessment approach to understanding the various feedbacks involved in the system. CoCEB is composed of a physical climate module, based on Earth's energy balance, and an economy module that uses endogenous economic growth with physical and human capital accumulation. We concentrate on the interactions between the two subsystems: the effect of climate on the economy, via damage functions, and the effect of the economy on climate, via control of greenhouse gas emissions. Simple functional forms of the relation between the two subsystems permit simple interpretations of the coupled effects. The CoCEB model is used to evaluate hypotheses on the long-term effect of investment in emission abatement, and on the comparative efficacy of different approaches to abatement. In this paper, we consider investments in low-carbon technologies. Carbon capture and storage (CCS), along with deforestation reduction, will be dealt with in Part 2. The CoCEB model is highly flexible and transparent;

25 as such, it allows one to easily formulate and compare different functional representations of climate change mitigation policies. Using different mitigation measures and their cost estimates, as found in the literature, one is able to compare these measures in a coherent way. While many studies in the climate-economic literature treat abatement costs merely as an unproductive loss of income, this paper shows that mitigation costs do slow down economic growth over the next few decades, but only up to the mid-21st century or even earlier; growth reduction is compensated later on by having avoided negative impacts of climate change on the economy. 


\section{Introduction and motivation}

Global warming is one of the most profound and urgent challenges in environmental research because of its potential impacts on society and the economy (Dong et al., 2013; Chang et al., 2016). The vast evidence for the changes in Earth's climate being due to a major extent to the anthropogenic increase in greenhouse gases (GHGs) is comprehensively compiled

5 in the successive reports of the Intergovernmental Panel on Climate Change (IPCC, 1996a, 2001, 2007a, 2013), carbon dioxide $\left(\mathrm{CO}_{2}\right)$ being the largest contributor (Mokhov et al., 2012); see also Hay (2013, p. 899) or Idso et al. (2013).

Over $80 \%$ of today's energy comes from fossil fuels (Akaev, 2015): together with land-use change, they are the major anthropogenic source of $\mathrm{CO}_{2}$ (Palmer and Engel, 2009; Diesendorf, 2012; Akaev, 2015). There is widespread consensus that significant carbon emission reductions, including reductions to zero net carbon during the 21 st century, must be an integral

10 part of a common strategy for addressing climate change (Bowen, 2014; Schellnhuber et al., 2016). Low-carbon technologies for the production, delivery, and conversion of energy will play a key role in these strategies; see also Barron and McJeon (2015). A key remaining question, though, is that of the effect on economic growth of the various measures that might be taken to keep the end-of-century warming below 2 degrees Celsius $\left(2{ }^{\circ} \mathrm{C}\right)$ above pre-industrial levels.

Typically, the link of the global economy to GHG emissions and the effect of global warming on the economic system are

15 modeled using integrated assessment models [IAMs; Garrett (2015)]. There are more than 20 IAMs used so far in climate policy analyses (Rosen, 2016). They differ with respect to modeling structure, complexity and assumptions regarding the way the climate system and the socio-economic system function and interact (Zaddach, 2016, p. 5). Ortiz and Markandya (2009) and Stanton et al. (2009) review some of these models; see also Meyers (2012, pp. 5399-5428), Pindyck (2013), Stern (2013), Brock et al. (2014) and Brock and Xepapadeas (2015) for a review and critique of the relevant literature on

20 IAMs in climate economics, as well as recent literature on inter-temporal, spatial and dynamic environmental economic modeling.

IAMs are motivated by the need to balance the dynamics of carbon accumulation in the atmosphere and the dynamics of de-carbonization of the economy (Nordhaus, 1994a). Basically, these studies consist in choosing the path for productive investment and emission abatement that maximize welfare (Bréchet et al., 2015). However, in analyzing the economic

25 implications of climate policies, these models often assume that the growth rate of the economy is exogenously given, and feedback effects of lower GHGs concentrations in the atmosphere on economic growth are frequently neglected. For example, Nordhaus and Boyer (2000) analyze different abatement scenarios, in which the Gross Domestic Product (GDP) growth rate is assumed to be an exogenous variable and the results are compared with the social optimum. Also, the fundamental alterations in wealth holdings are systematically downplayed by the practices of current integrated assessment 30 modeling (DeCanio, 2003, p. 12).

In this paper, we study the interaction between global warming and economic growth, along the lines of the Dynamic Integrated model of Climate and the Economy (DICE) of Nordhaus (1994a), with subsequent updates in Nordhaus and Boyer (2000), Nordhaus (2007, 2008) and Nordhaus and Sztorc (2013), while removing some of the limitations above.

Greiner $(2004,2015)$ extended the DICE framework by including endogenous growth, to account for the fact that 35 environmental policy affects not only the level of economic variables but also the long-run growth rate; see also Greiner and Semmler (2008). Using the extended DICE model, Greiner argues that higher abatement activities reduce GHG emissions and may lead to a rise or decline in growth. The net effect on growth depends on the specification of the function between the economic damage and climate change.

Anthropogenic GHGs are the result of economic activities (Garrett, 2015) and the growth in $\mathrm{CO}_{2}$ emissions closely 40 follows the growth in GDP (Creamer and Gao, 2015, p. 5), corrected for improvements in energy efficiency (Friedlingstein, et al., 2010). Thus, the main shortcoming in Greiner's $(2004,2015)$ approach is that of treating industrial $\mathrm{CO}_{2}$ emissions, due to combustion of fossil fuels, as constant over time. Another problematic aspect of Greiner's emissions formulation is its 
inability to allow for a total absence of abatement activities: in fact, his formulation only holds for a minimum level of abatement.

We address these issues in the present Part 1 of a two-part paper by using a novel approach to formulating emissions that depend on economic growth and vary over time; in this approach, abatement equal to zero corresponds to Business As Usual

5 (BAU). Our model explicitly includes the causal links between economic growth and the climate change-related damages via the increase of $\mathrm{CO}_{2}$ emissions. In particular, it can show how to alter this relationship by the use of various mitigation measures geared toward reduction of $\mathrm{CO}_{2}$ emissions (Metz et al., 2007; Hannart et al., 2013). We will use the abatement share to invest in the increase of overall energy efficiency of the economy and decrease of overall carbon intensity of the energy system; see Diesendorf (2014, p. 143) and Equation (14) below.

10 The companion paper, Part 2, complements the model by introducing a biosphere component, along with a representation of carbon capturing and storing (CCS) technologies and control of deforestation, as well as increasing photosynthetic biomass sinks as a method of controlling atmospheric $\mathrm{CO}_{2}$ and consequently the intensity and frequency of climate change related damages.

Our Coupled Climate-Economy-Biosphere (CoCEB) model is not intended to give a detailed quantitative description of

15 all the processes involved nor to make specific predictions for the latter part of this century. The CoCEB model is a reducedcomplexity model that tries to incorporate the climate-economy-biosphere interactions and feedbacks with the minimum amount of variables and equations needed. We thus wish to trade greater detail for greater flexibility and transparency of the dynamical interactions between the different variables.

As different types of fossil fuels produce different volumes of $\mathrm{CO}_{2}$ in combustion, the dynamics of fossil fuel

20 consumption - that is, the relative shares of coal, oil, and natural gas - has to be taken into account when calculating the future dynamics of $\mathrm{CO}_{2}$ emission; see also Akaev (2015). These shares are not known at the present time (Akaev, 2015) nor is it easy to predict their evolution. In order to describe the dynamics of hydrocarbon-based energy share in the global energy balance of the 21st century and their replacement with renewable energy sources we use, following Sahal (1985), logistic functions; see also Garrett (2015).

25 Various climate change mitigation measures have been considered heretofore. Still, many IAMs in the contribution of Working Group 3 to the Fifth Assessment Report of the IPCC (Clarke et al., 2014) treat abatement costs merely as an unproductive loss of income (Edenhofer et al., 2015; Stoknes, 2015, p. 59) and conclude that limiting total human-induced warming to less than $2{ }^{\circ} \mathrm{C}$ can be achieved by carbon emissions reductions and establishment of a low-carbon economy on their own; see also Edmonds et al. (2013), Wasdell (2015), DDPP (2015), and Rogelj et al. (2015, Table 1). Our CoCEB

30 model innovates in (i) making emissions depend on economic growth; and (ii) treating investment in abatement not as a pure loss but as a way to increase the overall energy efficiency of the economy and decrease the overall carbon intensity of the energy system.

Our study will also point to the fact that investment in low- and zero-carbon technologies alone is a necessary (Kriegler et al., 2014, and references therein) but not sufficient step towards global climate stabilization: no matter how fast $\mathrm{CO}_{2}$

35 emissions are reduced, the $2{ }^{\circ} \mathrm{C}$ target will still be violated; see also Held et al. (2009), Pielke (2010), Scott (2014, p. 21), Akaev (2015) and Wasdell (2015). The inability of low- and zero-carbon technologies alone to produce effective climate change mitigation may partly be attributed to the warming from the carbon stock already in the atmosphere (e.g., Held et al., 2009; Steffen, 2012; Wasdell, 2015) and the "rebound effect" (Jevon's paradox) whereby gains in efficiency are offset by increased consumption or new uses for energy (Garrett, 2012; Palmer, 2012).

40 The CoCEB model is, like all models, sensitive to the choice of key parameters. We do carry out a sensitivity study, but do not intend to make precise calibrations for a quantitative projection of the climate-and-economy evolution throughout the $21^{\text {st }}$ century. Rather, we want to provide a tool for studying qualitatively how various climate policies affect the economy. 
The next section describes the theoretical model, especially detailing the additions with respect to Nordhaus and Sztorc (2013), Greiner (2004, 2015) and Greiner and Semmler (2008). Section 3 discusses the numerical simulations and results, while Sect. 4 tests the sensitivity of the results to key parameters. Section 5 concludes, compares CoCEB to previous studies, and offers caveats and avenues for future research.

\section{Model description}

In this section we present our theoretical model. First, we sketch the physical climate module and then we describe the interrelation between economic activities and the change in the average global surface temperature.

\subsection{Climate module}

The time evolution of the average surface air temperature $T$ (SAT) on Earth is given by

$10 \frac{\mathrm{d} T}{\mathrm{~d} t}=\frac{\left(1-\alpha_{\mathrm{T}}\right) \mathrm{Q}}{4 c_{\mathrm{h}}}-\frac{\varepsilon \sigma_{\mathrm{T}} \tau_{\mathrm{a}}}{c_{\mathrm{h}}} T^{4}+\frac{6.3 \beta_{1}(1-\xi)}{c_{\mathrm{h}}} \operatorname{In}\left(\frac{C}{\hat{C}}\right)$,

see, for instance, Ghil and Childress (1987, Ch. 10), McGuffie and Henderson-Sellers (2005, pp. 81-85), Hans and Hans (2013, Ch. 2) or Fraedrich et al. (2016). Here the first and second terms on the right-hand side are incoming and outgoing radiative fluxes respectively, while the third term is radiative forcing due to increase in GHGs (Kemfert, 2002; Greiner and Semmler, 2008; Greiner, 2015); $\sigma_{\mathrm{T}}$ is the Stefan-Boltzmann constant, $\tau_{\mathrm{a}}$ the infrared (long-wave) transmissivity of the

15 atmosphere, $\varepsilon$ the emissivity that gives the ratio of actual emission to blackbody emission, $\alpha_{\mathrm{T}}$ the mean planetary albedo, $\mathrm{Q}$ is the average solar constant.

The specific heat capacity $c_{\mathrm{h}}$ of Earth as a whole is largely determined by the oceans (Levitus et al., 2005); here it is taken equal to $16.7 \mathrm{~W} \mathrm{~m}^{-2} \mathrm{~K}^{-1}$ (Schwartz, 2007, 2008), which corresponds to an ocean fractional area of 0.71 and a depth of 150-700 m of the ocean active layer; see also Abdussamatov (2016). The current $\mathrm{CO}_{2}$ concentration $C$ is given in gigatons

20 of carbon $\left(\mathrm{GtC}, 1 \mathrm{Gt}=10^{15} \mathrm{~g}\right)$ and $\hat{C}$ is the pre-industrial $\mathrm{CO}_{2}$ concentration. All the feedbacks of GHG concentration on global temperature are represented in this highly idealized model by the factor $\beta_{1}$, which is usually assumed to take values between 1.1 and 3.4 (Greiner and Semmler, 2008, p. 62; Greiner, 2015); in this study, we took $\beta_{1}=3.3$. The parameter $\xi=0.23$ captures the fact that part of the warmth generated by the greenhouse effect is absorbed by the oceans and transported from their upper layers to the deep sea (Greiner and Semmler, 2008; Greiner, 2015). The other parameters have standard values that are listed in Table 1 .

At equilibrium, that is for $\mathrm{d} T / \mathrm{d} t=0$, Eq. (1) gives an average SAT of $14{ }^{\circ} \mathrm{C}$ for the pre-industrial GHG concentration, i.e. for $C=\hat{C}$; see also Nordhaus and Boyer (2000) and Dong et al. (2013, p. 164, Fig. 3.22). Doubling the $\mathrm{CO}_{2}$ concentration in Eq. (1) yields an increase of about $3{ }^{\circ} \mathrm{C}$ in equilibrium temperature, to $17{ }^{\circ} \mathrm{C}$. This increase lies within the range of IPCC estimates, between about 1.5 and $4.5^{\circ} \mathrm{C}$ (Charney et al., 1979; IPCC, 2013, pp. 924-926) with a best estimate

30 of about $3.0^{\circ} \mathrm{C}$ (IPCC, 2007a, p. 12).

Humanity's most important influence on the climate system is via the carbon cycle (Richardson et al., 2011, p. 92). While there is some discussion on the representation of the carbon cycle in IAMs (see Glotter et al., 2014; Traeger, 2014), we represent the evolution $C$ of the concentration of $\mathrm{CO}_{2}$ in the atmosphere, following Uzawa (2003), Greiner and Semmler (2008), and Greiner (2015), by

$35 \frac{d C}{d t}=\beta_{2} E_{\mathrm{Y}}-\mu_{\mathrm{o}}(C-\hat{C})$.

Here $E_{\mathrm{Y}}$ stands for the industrial $\mathrm{CO}_{2}$ emissions. The fact that part of the emissions leaves the atmosphere and is taken up by the oceans is reflected in Eq. (2) by the parameter $\beta_{2}$ (see IPCC, 2001, p. 39; Hüsler and Sornette, 2014); the excess $C$ 

of $\mathrm{CO}_{2}$ equals $\mu_{o}$ and it is estimated in the literature to lie within an uncertainty range that spans 0.005-0.2 (IPCC, 2001, p. 38); we take it here to equal $\mu_{o}=1 / 120=0.0083$, i.e. closer to the lower end of the range (IPCC, 2001, p. 38); see also Nordhaus (1994a, p. 21).

\section{$5 \quad 2.2$ Economy module}

In Greiner $(2004,2015)$ and Greiner and Semmler (2008) the per capita GDP, $Y$, is given by a modified version of a constant-return-to scale Cobb-Douglas production function (Cobb and Douglas, 1928; see also Romer, 2012),

$Y=\mathrm{A} K^{\alpha} H^{1-\alpha} D(T-\hat{T})$.

Here $K$ is the per capita physical capital, $H$ is the per capita human capital, $A>0$ the total factor of productivity,

$100<\alpha<1$ is the capital share, and $D(T-\hat{T})$ is the damage, expressed as a function of the temperature difference due to climate change. The damage function is described in Sect. 2.4 below.

The economy income identity in per capita variables is given by $Y-X=I+M_{\mathrm{E}}+G_{\mathrm{E}}$,

with $X=\tau Y$ the (per capita) tax revenue, $0<\tau<1$ the per annum tax rate, $I$ investment, $M_{\mathrm{E}}$ consumption, and $G_{\mathrm{E}}$

15 abatement activities. This means that national income after tax is used for investment, consumption, and abatement. We assume that $G_{\mathrm{E}}$ is expressed as a fraction of $X$,

$G_{\mathrm{E}}=\tau_{\mathrm{b}} X=\tau_{\mathrm{b}} \tau Y$,

with $0 \leq \tau_{\mathrm{b}}<1$ the ratio of per annum abatement share, used as a policy tool. Consumption is also expressed as a fraction of $Y$ after tax, that is,

$20 M_{\mathrm{E}}=c(1-\tau) Y$,

with $0<c<1$ the global annual consumption share.

The accumulation of per capita physical capital $K$ is assumed to obey

$\frac{\mathrm{d} K}{\mathrm{~d} t}=Y-X-M_{\mathrm{E}}-G_{\mathrm{E}}-\left(\delta_{\mathrm{K}}+n\right) K$,

the logistic-type human population growth rate $0<n<1$ is given, in turn, by

$25 \frac{\mathrm{d} n}{\mathrm{~d} t}=\left(\frac{1}{1+\delta_{\mathrm{n}}}-1\right) n$,

with $\delta_{n}$ being the per year decline rate of $n$, and $\delta_{\mathrm{K}}$ the per year depreciation rate of physical capital. Substituting the definitions of $Y, X, M_{\mathrm{E}}$, and $G_{\mathrm{E}}$ into Eq. (7) we get

$\frac{\mathrm{d} K}{\mathrm{~d} t}=\mathrm{A}\left[1-\tau\left(1+\tau_{\mathrm{b}}\right)-c(1-\tau)\right] K^{\alpha} H^{1-\alpha} D(T-\hat{T})-\left(\delta_{\mathrm{K}}+n\right) K$.

For physical capital to increase, $\mathrm{d} K / \mathrm{d} t>0$, the parameters must satisfy the inequality $0<\left[\tau\left(1+\tau_{\mathrm{b}}\right)+c(1-\tau)\right]<1$. Now,

30 proceeding as above for $K$, we assume that the per capita human capital $H$ evolves over time as

$\frac{\mathrm{d} H}{\mathrm{~d} t}=\varphi\left\{\mathrm{A}\left[1-\tau\left(1+\tau_{\mathrm{b}}\right)-c(1-\tau)\right] K^{\alpha} H^{1-\alpha} D(T-\hat{T})\right\}-\left(\delta_{\mathrm{H}}+n\right) H$,

here $\varphi>0$ is a coefficient that determines how much any unit of investment contributes to the formation of the stock of knowledge and $\delta_{\mathrm{H}}$ gives the depreciation of knowledge. 
Note that we take, as a starting point, the Solow-Swan approach (Solow, 1956; Swan, 1956; Greiner and Semmler, 2008), in which the share of consumption and saving are given. We do this because we want to focus on effects resulting from climate change, which affect production as modeled in Eqs. (3)-(10) and, therefore, neglect effects resulting from different preferences. Our model's macroeconomic production function only considers per capita physical capital and per capita

5 human capital as inputs and, like in the DICE model, does not consider, at this point, energy as an input to the production function. Nor does the CoCEB model version in this paper consider carbon pricing, e.g. via a tax on emissions.

Our formulation assumes, furthermore, that government spending, except for abatement, does not affect the size of per capita GDP: on the one hand, an increase in abatement activities, leads to a higher value of the abatement share $\tau_{\mathrm{b}}>0$, and it makes the difference $1-\left[\tau\left(1+\tau_{\mathrm{b}}\right)+c(1-\tau)\right]$ in Eqs. (9) and (10) smaller. Hence the two factors of production - per

10 capita physical capital and per capita human capital - decrease, and hence production in turn decreases. On the other hand, a reduction in $\mathrm{CO}_{2}$ emissions that is due to the government's spending on abatement activities lessens the intensity of GHGs and hence the climate-change related damages to the economy.

Emissions of $\mathrm{CO}_{2}$ are a byproduct of production (Barker et al., 1995, p .4) and hence are a function of per capita output relative to per capita abatement activities. This implies that a higher production goes along with higher emissions (Creamer

15 and Gao, 2015, p. 5) for a given level of abatement spending. This assumption is frequently encountered in environmental economics (e.g., Smulders, 1995). It should also be mentioned that $\mathrm{CO}_{2}$ emissions affect production indirectly by affecting the Earth's climate, which leads to a higher SAT and to an increase in the number and intensity of climate-related disasters (see, e.g., Creamer and Gao, 2015; Wagner and Weitzman, 2015).

\subsection{Industrial $\mathrm{CO}_{2}$ emissions}

20 Here, in order to formulate emissions $E_{\mathrm{Y}}$ so that they may vary over time and to allow abatement to be zero, we specifically

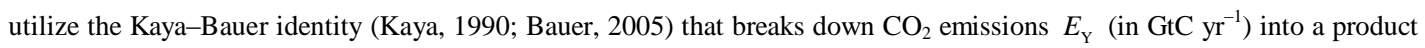
of five components: emissions per unit of energy consumed (carbon intensity of energy), energy use per unit of aggregate GDP (energy intensity), per capita GDP, human population, and carbon emission intensity, as shown below:

$$
\begin{array}{rlrl}
E_{\mathrm{Y}} & =\left(\frac{E_{\text {tot }}}{\text { energy }}\right)\left(\frac{\text { energy }}{\bar{Y}}\right)\left(\frac{\bar{Y}}{L}\right) L\left(\frac{E_{\mathrm{Y}}}{E_{\mathrm{tot}}}\right) \\
& = & c_{\mathrm{c}} e_{\mathrm{c}} Y L \kappa_{\mathrm{ccs}} \\
& = & \sigma Y L \kappa_{\mathrm{ccs}} .
\end{array}
$$

25 Here $\bar{Y}$ is aggregate GDP, $Y=(\bar{Y} / L)$ is per capita GDP, $L$ is the human population, $c_{\mathrm{c}}=E_{\text {tot }} /$ energy is the carbon intensity of energy, $e_{\mathrm{c}}=$ energy $/ \bar{Y}$ is the energy intensity, $c_{\mathrm{c}} e_{\mathrm{c}}=E_{\mathrm{tot}} / \bar{Y}=\sigma$ is the ratio of industrial carbon emissions to aggregate GDP or the economy carbon intensity, $E_{\mathrm{Y}} / E_{\mathrm{tot}}=\kappa_{\mathrm{ccs}}$ is the fraction of emissions that is vented to the atmosphere and involves CCS.

The $E_{\mathrm{Y}}$ level also depends on abatement activities, as invested in the increase of overall energy efficiency in the 30 economy and decrease of overall carbon intensity of the energy system. The case of $\tau_{b}=0$ in Eq. (5) corresponds to unabated emissions, i.e. BAU. Emissions are reduced as the abatement share increases. Taking the natural logarithms and differentiating both sides of the Kaya-Bauer identity yields

$\frac{\mathrm{d} E_{\mathrm{Y}}}{\mathrm{d} t}=\left[g_{\sigma}+g_{\mathrm{Y}}+n+g_{\text {ccs }}\right] E_{\mathrm{Y}}$,

where $g_{\sigma}$ is the growth rate of $\sigma, g_{\mathrm{Y}}$ is the growth rate of $Y, n$ is the population growth rate and $g_{\text {ccs }}$ is the CCS growth rate. If CCS is applied, then $E_{\mathrm{Y}}<E_{\mathrm{tot}}$. There are many concerns and uncertainties about the CCS approach and it is usually 
not taken as a really sustainable and environmental friendly mitigation option to reduce emissions over a longer period (Tol, 2010; Bowen, 2014). We will not consider it in this Part 1 of the paper, that is, we take here $E_{\mathrm{Y}}=E_{\text {tot }}$ or $\kappa_{\text {ccs }}=1$.

We now formulate the technology-dependent carbon intensity $\sigma$. We follow the approach of Sahal (1985), who models the replacement of one technology by another using a logistic law. The energy intensity $e_{\mathrm{c}}$, in tons of reference fuel (TRF)

5 (USD 1000 of $\bar{Y})^{-1}$, is the share of hydrocarbon-based energy (coal, oil, and natural gas) in the global energy balance (GEB) of the twenty-first century. Its dynamics are described by a descending logistic function (Akaev, 2015),

$e_{\mathrm{c}}=f_{\mathrm{c}}\left[1-\frac{r \exp (\psi t)}{1+r(\exp (\psi t)-1)}\right]$.

Here we take 1990 as the time when the use of renewable energy sources — biomass and wastes, hydropower, geothermal energy, wind energy, and solar energy — and biofuels became significant in the GEB. The multiplier $f_{\mathrm{c}}=0.881$

10 corresponds to $1.0107 \times 10^{10} \mathrm{TRF}$ as the share of fossil fuels in the GEB $\left(1.1472 \times 10^{10} \mathrm{TRF}\right)$ in 1990 (Akaev, 2015, Table 21.4). The parameters $r$ and $\psi$ are derived by assuming a level of $95 \%$ fossil fuels used for year 2020 and of $5 \%$ for year 2160. They are $r=0.05$ and

$\psi=\psi_{0}\left(\frac{1}{1-\alpha_{\tau} \tau_{\mathrm{b}}}\right)$,

with $\psi_{0}=0.042$ and $\tau_{\mathrm{b}}$ is the abatement share; $\alpha_{\tau}>0$ here is an abatement efficiency parameter, chosen such that for the

15 path corresponding to $\tau_{\mathrm{b}}=0.075$, carbon emissions reduction from BAU is about $50 \%$ by year 2050; see Sect. 2.5 for details. Calculations based on Eq. (13) using these values indicate that the share of fossil fuels will be significant throughout the whole twenty-first century and, when $\tau_{\mathrm{b}}=0$, this share decreases to $35 \%$ only by its end (Akaev, 2015).

As different types of fossil fuels produce different volumes of $\mathrm{CO}_{2}$ in combustion, the dynamics of fossil fuel consumption - i.e., the relative shares of coal, oil, and natural gas - should be taken into account when calculating the future

20 dynamics of $\mathrm{CO}_{2}$ emission. Since these shares are not known at this time, we assume a logistic function for describing a reduction of the carbon intensity of energy $c_{\mathrm{c}}$, in tons of carbon (tC) TRF ${ }^{-1}$, throughout the 21st century (Akaev, 2015),

$c_{\mathrm{c}}=c_{-\infty}+\frac{a_{\mathrm{c}}}{1+r \exp (-\psi t)}$

with $a_{\mathrm{c}}>0$ a constant and $c_{-\infty}$ is the value of $c_{\mathrm{c}}$ before 1990 .

Thus the carbon intensity $\sigma$, which represents the trend in the $\mathrm{CO}_{2}$-output ratio, can now be given by the product of the energy intensity $e_{\mathrm{c}}$ in Eq. (13) and the carbon intensity of energy $c_{\mathrm{c}}$ in Eq. (15) as:

$\sigma=f_{\mathrm{c}}\left[1-\frac{r \exp (\psi t)}{1+r(\exp (\psi t)-1)}\right]\left[c_{-\infty}+\frac{a_{\mathrm{c}}}{1+r \exp (-\psi t)}\right]$.

We can now calculate the de-carbonization of the economy, i.e. the declining growth rate of $\sigma$, by taking the natural logarithms of Eq. (16) and getting the derivative with respect to time:

$g_{\sigma}=\frac{f_{\mathrm{c}}}{e_{\mathrm{c}}}\left\{\frac{[\psi r \exp (\psi t)][1+r(\exp (\psi t)-1)]-\left[\psi r^{2} \exp (\psi t)\right]}{[1+r(\exp (\psi t)-1)]^{2}}\right\}+\frac{1}{c_{\mathrm{c}}}\left\{\frac{a_{\mathrm{c}} \psi r \exp (-\psi t)}{[1+r \exp (-\psi t)]^{2}}\right\}$.

30 We note that the de-carbonization of the economy, i.e. the declining growth rate of the carbon intensity $\sigma$ in Eq. (16) is also assumed to be time-dependent. Fossil-fuel consumption has been subject to a gradual de-carbonization process since the early times of industrialization, by a transition — in chronological order- from the use of wood to coal, from coal to oil, and 
in the most recent past from coal and oil to natural gas (see also, Gerlagh and Van der Zwaan, 2003). The effect of the abatement share $\tau_{\mathrm{b}}$ is to make this process slower or faster.

In a similar way as Eq. (17) was derived from Eq. (16), the growth rate $g_{Y}$ of per capita output is obtained from Eq. (3)

as

$5 \quad \frac{1}{Y} \frac{\mathrm{d} Y}{\mathrm{~d} t}=\frac{\alpha}{K} \frac{\mathrm{d} K}{\mathrm{~d} t}+\frac{(1-\alpha)}{H} \frac{\mathrm{d} H}{\mathrm{~d} t}+\frac{1}{D} \frac{\mathrm{d} D}{\mathrm{~d} T} \frac{\mathrm{d} T}{\mathrm{~d} t}$,

or,

$g_{\mathrm{Y}}=\alpha g_{\mathrm{K}}+(1-\alpha) g_{\mathrm{H}}+\frac{1}{D} \frac{\mathrm{d} D}{\mathrm{~d} T} \frac{\mathrm{d} T}{\mathrm{~d} t}$,

with $g_{\mathrm{K}}$ the per capita physical capital growth and $g_{\mathrm{H}}$ the per capita human capital growth.

Human population evolves; cf. Golosovsky (2010), as

$10 \frac{\mathrm{d} L}{\mathrm{~d} t}=n L\{1-\exp [-(L / L(1990))]\}$,

where $n$ is the population growth rate as given in Eq. (8) and $L(1990)$ is the 1990 population. Equation (19) yields $L=$ $9 \times 10^{9}$ people in the year $t=2100$. This value is consistent with the 2100 population projections of scenarios in the literature (e.g. Van Vuuren et al., 2012, Table 3; Grinin and Korotayev, 2015, p. 197, Fig. B.12a).

\subsection{Damage function}

15 The damage function $D$ gives the decline in $Y$, the global GDP, which results from an increase of the temperature $T$ above the pre-industrial temperature $\hat{T}$. Nordhaus (1994a) formulates $D$ as

$D(T-\hat{T})=\left[1+m_{1}(T-\hat{T})^{\chi}\right]^{-1}$

with both the coefficient $m_{1}$ and the exponent $\chi$ positive, $m_{1}>0$ and $\chi>0$, while the damage is defined as $Y-D Y=(1-D) Y$. The greater the difference $T-\hat{T}$, the smaller will the value of $D(T-\hat{T})$ be, and thus the smaller the 20 value $D Y$ of the remaining GDP, after the damage.

The representation of climate change damages is both a key part and one of the weakest points of IAMs (Tol and Fankhauser, 1998). Nordhaus (1994a) used temperature originally as a proxy for overall climate change. This may have taken the research community's focus off from potentially dangerous changes in climate apart from temperature (Toth, 1995). However, without using a detailed climate model, temperature remains the best option available (Sanderson, 2002).

25 We assume, in choosing this option, that physical and human capitals are distributed across infinitely many areas in the economy, and that the strongly differential damages (Richardson et al., 2011, p. 245) by climate-related natural disasters are uncorrelated across areas. With such an assumption, some version of the law of large numbers can justify a result like Eq. (20) above; see Wouter Botzen and Van den Bergh (2012) and Dell et al. (2014) for an insightful discussion about the damage function.

30 In the original DICE calculations of Nordhaus (1994a), $\mathrm{CO}_{2}$ doubling was equivalent to a $3{ }^{\circ} \mathrm{C}$ warming, and he first estimated the damage from this doubling to be $1.33 \%$ of global GDP. Additionally, he argued that damage would increase sharply as temperature increases; hence he used a quadratic function, in which $\chi=2$, and $m_{1}$ is chosen to have $1.33 \%$ loss of GDP for a $3{ }^{\circ} \mathrm{C}$ warming.

Roughgarden and Schneider (1999), using the same functional form in Eq. (20), derived damage functions for each of the

35 disciplines represented in an expert opinion solicited by a climate change survey (Nordhaus, 1994b). Taking an average of their values, we get $m_{1}=0.0067$; see, for instance, Table 1 in Labriet and Loulou (2003). On the other hand, we calibrated 
the exponent $\chi=2.43$ so that our model's BAU emissions of $\mathrm{CO}_{2} \mathrm{yr}^{-1}$ and concentrations by 2100 mimic the Representative Concentration Pathway (RCP) 8.5 (Riahi et al., 2007; IPCC, 2013, p. 27, Table SPM.3); see Sect. 4.1 for details on our calibration of $\chi$. In fact, our projected climate change damages before and after abatement, as given by the damage function $D$ in Eq. (20), are consistent with the damages projected in Stern (2007); see also Creedy and Guest (2008), Chen et al. 5 (2012, p. 5), Moyer et al. (2013), Van Den Bergh (2015), as well as the further discussion in Sect. 5.2 below.

\subsection{Abatement measures and abatement share}

A key part of the mitigation literature concentrates on the feasibility of different climate targets, often defined by GHG concentrations or by radiative forcing levels, and the associated costs; see Van Vuuren et al. (2012) and the references therein. The broad range of options available for mitigating climate change includes the reduction of $\mathrm{CO}_{2}$ emissions -

10 increasing energy efficiency, increasing non-fossil fuel-based energy production, and the use of $\mathrm{CCS}-$ and $\mathrm{CO}_{2}$ removal (Bickel and Lane, 2010; Edenhofer et al., 2012; Steckel et al., 2013; Creamer and Gao, 2015).

The Paris Agreement duly reflects the latest scientific understanding of systemic global warming risks. Stabilizing GHG concentrations, and hence temperatures, requires transformational change across the board of modernity (Schellnhuber, 2016); see Appendix A for more details.

15 We now determine the abatement share, $\tau_{\mathrm{b}}$, which is the ratio of abatement spending to the tax revenue, cf. Eq. (5), and is being used here as a policy tool. The abatement share is used in the de-carbonization of the economy, cf. Eq. (16), through the parameter $\psi=\psi_{0}\left[1 /\left(1-\alpha_{\tau} \tau_{\mathrm{b}}\right)\right]$; see also Eq. (14).

The abatement costs of several IAMs tend to cluster in the range of about 1-2\% of GDP as the cost of cutting carbon emissions from BAU by $50 \%$ in the period 2025-2050, and about 2.5-3.5\% of GDP as the cost of reducing emissions from

20 BAU by about $70 \%$ by 2075-2100 (Tol, 2010, p. 87, Fig. 2.2; Van Den Bergh, 2015). Clarke et al. (2014) show that, as higher emission reduction targets are set, the uncertainty increases and so does the dispersion of results.

The gross costs in IAMs typically do not include any estimate of the benefits of climate change mitigation and usually do not include offsets from any so-called "co-benefits," such as reduced damages from air pollution on human health and on crop productivity (Barker and Jenkins, 2007), greater energy security, greater access to energy services for the poor, higher

25 rates of innovation (Bowen, 2014), and creation of new industries and jobs (Flavi and Engelman, 2009). Nor do they usually include benefits from policy reforms designed to correct market failures standing in the way of climate change mitigation, apart from carbon pricing to address the central GHG externality (Bowen, 2014). To obviate the shortcomings of this omission, we now include such benefits - albeit in an aggregate, highly idealized manner — in the CoCEB model.

Using the definition of abatement in Eq. (5), the GDP evolution in Eq. (3) and an annual tax rate $\tau=0.2$ (Greiner and

30 Semmler, 2008), we obtain an abatement share that gives an abatement cost equivalent to $1 \%$ of GDP by 2050 to be $\frac{G_{\mathrm{E}}}{Y}=\tau_{\mathrm{b}} \tau=0.01 \Rightarrow \tau_{\mathrm{b}}=0.05$

Similarly, the abatement share giving an abatement cost equivalent to $2 \%$ of GDP by 2050 is $\tau_{\mathrm{b}}=0.1$. We take, as our lower abatement share, the average $\tau_{b}=0.075$ of the two abatement shares above; this $\tau_{b}$-value gives an abatement cost equivalent to $1.5 \%$ of GDP by 2050 .

35 Next, we choose the abatement efficiency parameter $\alpha_{\tau}=1.8$ such that, for the path corresponding to $\tau_{\mathrm{b}}=0.075$, carbon emissions reduction from BAU is about $50 \%$ by 2050 . Our scenario corresponding to $\tau_{\mathrm{b}}=0.075$ also happens to mimic the RCP6.0 by 2100 (Hijioka et al., 2008). For the other non-BAU scenarios, we choose abatement shares of $\tau_{b}=0.11$ and 0.145 , such that an emissions reduction of $50 \%$ or more from BAU by 2050 and beyond gives a reduction in GDP of 2.2 and $2.9 \%$, respectively; the scenario given by $\tau_{\mathrm{b}}=0.11$ also mimics RCP4.5 (Wise et al., 2009). Note that the abatement shares in Greiner (2004) and Greiner and Semmler (2008), which use Eq. (11), are about 10 times lower than the ones chosen here. 


\subsection{Summary formulation of COCEB}

Our coupled CoCEB model is described by Eqs. (1), (2), (9), (10) and (12). The model describes the temporal dynamics of five variables: per capita physical capital $K$, per capita human capital $H$, the average global surface air temperature $T$, the $\mathrm{CO}_{2}$ concentration in the atmosphere $C$, and industrial $\mathrm{CO}_{2}$ emissions $E_{\mathrm{Y}}$. The other variables are connected to these five

5 independent variables by algebraic equations. In Part 2, a supplementary equation will be added for the biomass.

The equations are grouped for the reader's convenience below:

$$
\begin{aligned}
\frac{\mathrm{d} K}{\mathrm{~d} t} & =\mathrm{A}\left[1-\tau\left(1+\tau_{\mathrm{b}}\right)-c(1-\tau)\right] K^{\alpha} H^{1-\alpha} D(T-\hat{T})-\left(\delta_{\mathrm{K}}+n\right) K, \\
\frac{\mathrm{d} H}{\mathrm{~d} t} & =\varphi\left\{\mathrm{A}\left[1-\tau\left(1+\tau_{\mathrm{b}}\right)-c(1-\tau)\right] K^{\alpha} H^{1-\alpha} D(T-\hat{T})\right\}-\left(\delta_{\mathrm{H}}+n\right) H \\
\frac{\mathrm{d} T}{\mathrm{~d} t} & =\frac{\left(1-\alpha_{\mathrm{T}}\right) \mathrm{Q}}{4 c_{\mathrm{h}}}-\frac{\varepsilon \tau_{\mathrm{a}} \sigma_{\mathrm{T}}}{c_{\mathrm{h}}} T^{4}+\frac{(6.3) \beta_{1}(1-\xi)}{c_{\mathrm{h}}} \operatorname{In}\left(\frac{C}{\hat{C}}\right), \\
\frac{\mathrm{d} C}{\mathrm{~d} t} & =\beta_{2} E_{\mathrm{Y}}-\mu_{\mathrm{o}}(C-\hat{C}) \\
\frac{\mathrm{d} E_{\mathrm{Y}}}{\mathrm{d} t} & =\left[g_{\sigma}+g_{\mathrm{Y}}+n\right] E_{\mathrm{Y}} .
\end{aligned}
$$

The parameter values used in the model are as described in the text above and in Table 1 below. They have been chosen according to standard tables and previous papers.

\section{Numerical simulations and abatement results}

In the following, we confine our investigations to the transition path for the 110 years from the baseline year 1990 to the end of this century. The 1990 baseline is chosen, since it is the baseline often used in the Kyoto Protocol (Richardson et al., 2011, Chap. 13) as well as in a number of other international discussions concerning emissions reductions (Richardson et al., 2011, p. 284).

15 De Vries (2007) advises that one should not evaluate more than three or four scenarios at a time, because people cannot handle more due to cognitive limitations. We therefore consider four scenarios with an aggregate $\mathrm{CO}_{2}$ concentration larger than or equal to the pre-industrial level: (i) a BAU scenario, with no abatement activities, i.e., $\tau_{\mathrm{b}}=0$; and (ii)-(iv) three scenarios with increasing abatement measures that correspond to $\tau_{\mathrm{b}}=0.075,0.11$ and 0.145 , respectively, as chosen in Sect. 2.5 .

20 The CoCEB model is integrated in time starting from the initial values at year 1990, as listed in Table 1. The damage function exponent $\chi$ in Eq. (20) is taken to be super-quadratic, $\chi=2.43$; all other parameter values are as in Table 1 . The time step is 1 year and the integration is stopped at year 2100. The values of $\mathrm{CO}_{2}$ emissions and concentration, temperature, damage and per capita GDP growth at the end of the integrations are shown in Table 2 for the four scenarios.

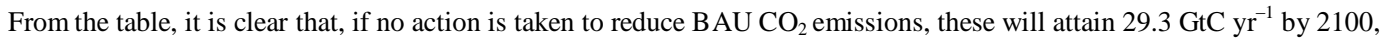

25 leading to an atmospheric $\mathrm{CO}_{2}$ concentration of $1842 \mathrm{GtC}$, i.e. about 3.1 times the pre-industrial level at that time. As a consequence, global average SAT will rise by $5.2{ }^{\circ} \mathrm{C}$ from the pre-industrial level, and the corresponding damage to the per capita GDP will be of $26.9 \%$. This finding compares favorably with the IPCC results for their RCP8.5 scenario, cf. Table 4 below.

The year-2100 changes in our three non-BAU scenarios' global mean SAT from the pre-industrial level are 3.4, 2.6, and 2

$30{ }^{\circ} \mathrm{C}$. The RCP6.0, RCP4.5, and RCP2.6 give a similar range of change in global SAT of $1.4-3.1{ }^{\circ} \mathrm{C}$ with a mean of $2.2{ }^{\circ} \mathrm{C}$, $1.1-2.6{ }^{\circ} \mathrm{C}$ with a mean of $1.8{ }^{\circ} \mathrm{C}$, and $0.3-1.7^{\circ} \mathrm{C}$ with a mean of $1{ }^{\circ} \mathrm{C}$, respectively (IPCC, 2013, p. 23, Table SPM.2). We 
note that our changes in temperature from our scenarios are fairly similar in magnitude to the IPCC ones; see also Dong et al. (2013, p. 8, Fig. 2.1).

The cumulative $\mathrm{CO}_{2}$ emissions for the 1990-2100 period in this study's non-BAU scenarios are 1231, 1037, and 904 GtC. On the other hand, for the 2012-2100 period, RCP6.0 gives cumulative $\mathrm{CO}_{2}$ emissions in the range of 840-1250 GtC

5 with a mean of $1060 \mathrm{GtC}$; RCP4.5 gives a range of 595-1005 GtC with a mean of $780 \mathrm{GtC}$, while RCP2.6 gives a range of 140-410 GtC with a mean of 270 GtC (IPCC, 2013, p. 27, Table SPM.3). The two former RCPs agree rather well with our results, while RCP2.6 is less pessimistic.

In Fig. 1, the time-dependent evolution of the CoCEB output is shown, from 1990 to 2100 . The figure shows that an increase in the abatement share $\tau_{b}$ from 0 to 0.145 leads to lower $\mathrm{CO}_{2}$ emissions per year (Fig. 1a) as well as to lower

10 atmospheric $\mathrm{CO}_{2}$ concentrations (Fig. 1b) and, as a consequence, to a lower average global SAT (Fig. 1c), compared to the BAU value. This physical result reduces the economic damages (Fig. 1d) and hence the GDP growth decrease is strongly modified (Fig. 1e); see also Bréchet et al. (2015, Figs. 6.1-6.3).

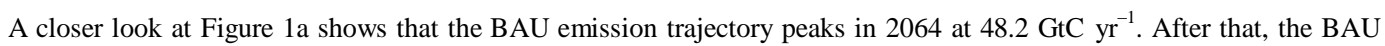
trajectory drops back and, in doing so, approaches the $\mathrm{CO}_{2}$ emissions of the RCP8.5 scenario by 2100 , at an emissions level

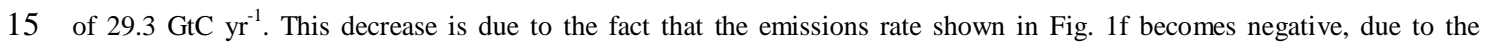
decarbonization of the economy, according to Eqs. (17) and (22e).

In fact, our BAU scenario's energy technology is assumed constant at its 1990 level, in agreement with the IPCC BAU scenario; see Edmonds et al. (2004, p. 77) and Pielke et al. (2008) and Hay (2013, pp. 903-904). Our BAU $\mathrm{CO}_{2}$ emissions are fairly similar to other scenarios given in the literature as well; see, for instance IPCC (2007c, Fig. TS.7), and Clarke et al.

20 (2014, Fig. 6.4, left panel).

Figure 1e is a key result of our study: it shows that abatement policies do pay off in the long run. From the figure, we see that - because of mitigation costs - per capita GDP growth on the paths with nonzero abatement share, $\tau_{\mathrm{b}} \neq 0$, lies below growth on the BAU path for the earlier time period, approximately between 1990 and 2060. Later though, as the damages from climate change accumulate on the BAU path (Fig. 1d), GDP growth on the BAU path (dashed) slows and falls below

25 the level on the other paths (solid, dash-dotted and dotted), i.e., the paths cross. This result agrees with those of many other analyses in the literature, in which economic growth in the long run is higher with mitigation than without it; see, for instance, Guest (2010, Fig. 1), Richardson et al. (2011, p. 320), and Bréchet et al. (2015, Figs. 6.1 and 6.2).

This crossing of the paths means that mitigation allows GDP growth to continue on its upward path in the long run, while carrying on BAU leads to great long-term losses; see also Stern (2007, p. 35) and Bréchet et al. (2015); the simulations in the

30 latter paper reveal that these losses may be much higher than usually appraised with IAMs in the literature because these IAMs define poorly their BAU scenario.

As will be shown in Table 3 below, the losses from mitigation in the near future are outweighed by the later gains in averted damage; see also, Stern (2007, p. 35, Fig. 2.3). The crossover time after which abatement activities pay off occurs around year 2060; its exact timing depends on the definition of damage and on the efficiency of the modeled abatement

35 measures in reducing emissions; see also Bréchet et al. (2015).

The average annual growth rates (AAGRs) of per capita GDP between 1990 and 2100, are given in our model by $(1 / 110) \sum_{t=1990}^{t=2100} g_{\mathrm{Y}}(t)$ and their values, starting from the BAU scenario, are $2.6,2.4,2.1 \%$, and $1.8 \% \mathrm{yr}^{-1}$, respectively, see again Fig. 1e. Relative to 1990, these correspond to approximate per capita GDP increases of 5.5-14.5 times, that is USD $_{1990}$ $34 \times 10^{3}-90 \times 10^{3}$ in year 2100, up from an approximate per capita GDP of USD $6 \times 10^{3}$ in 1990 . Our scenarios' AAGRs

40 and the 2100-to-1990 per capita GDP ratio agree well with scenarios from other studies, which give AAGRs of 0.4-2.7\% $\mathrm{yr}^{-1}$ and a per capita GDP increase of 3-21 fold, corresponding to $\mathrm{USD}_{1990} 15 \times 10^{3}-106 \times 10^{3}$ (Nakićenović and Swart, 
2000; Schrattenholzer et al., 2005, p. 59; Nordhaus, 2007; Stern, 2007; Van Vuuren et al., 2012; Krakauer, 2014; Bréchet et al., 2015).

Now, according to the United Nations Framework Convention on Climate Change (UNFCCC, 2009, 2015), the average global SAT should not exceed its pre industrial level by more than $2^{\circ} \mathrm{C}$; see also Akaev (2015) and Kuckshinrichs and Hake

5 (2015, pp. 1 and 289). This SAT target means that global efforts to restrict or reduce $\mathrm{CO}_{2}$ emissions must aim at an atmospheric $\mathrm{CO}_{2}$ concentration of no more than $958.5-1171.5 \mathrm{GtC}$ by year 2100 (Akaev, 2015).

This $\mathrm{CO}_{2}$ target can be achieved if carbon emissions are reduced to no more than $3.3 \mathrm{GtC} \mathrm{yr}^{-1}$, or nearly half relative to

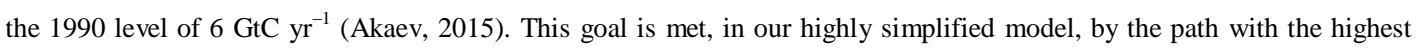
abatement share of the four, $\tau_{\mathrm{b}}=0.145$. From Table 2 and Fig. 1, we notice that this level of investment in the increase of

10 overall energy efficiency of the economy and decrease of overall carbon intensity of the energy system enable emissions to decrease to $2.5 \mathrm{GtC} \mathrm{yr}^{-1}$ by year 2100 (Fig. 1a), about a $58 \%$ drop below the 1990 emissions level; see also DDPP (2015). This emissions drop enables the deviation from pre-industrial SAT to reach no higher than $2{ }^{\circ} \mathrm{C}$ by year 2100 (Fig. 1c).

A number of studies (Calvin et al., 2009; Edmonds et al., 2013; Bowen, 2014; Clarke et al., 2014, and references therein; DDPP, 2015; Rogelj et al., 2015) have shown that achieving even smaller increases of SAT than the $2{ }^{\circ} \mathrm{C}$ level by 2100 is

15 technologically feasible and that it is also likely to be economically affordable. Our $\tau_{\mathrm{b}}=0.145$ scenario, however, cannot guarantee a deviation from pre-industrial SAT that is substantially less than $2{ }^{\circ} \mathrm{C}$ by 2100 .

In Table 3, we compare per capita abatement costs $G_{\mathrm{E}}=\tau_{\mathrm{b}} X=\tau_{\mathrm{b}} \tau Y$ and the damage costs $(1-D) Y$ for the year 2100, for each one of our emission reduction paths; these are given in Eqs. (5) and (20), respectively. From the table one notices that, not surprisingly, the more one invests in abatement, the more emissions are reduced relative to BAU and the less the

20 cost of damages from climate change; see also Edenhofer et al. (2015, Table 12.1). Tables 2 and 3 show that limiting global average SAT to no more $2{ }^{\circ} \mathrm{C}$ over pre-industrial levels would require an emissions reduction of $92 \%$ from BAU by 2100 , at a per capita cost of $\mathrm{USD}_{1990} 990$, i.e., an aggregate of $\mathrm{USD}_{1990} 8.1$ trillion, which translates to $2.9 \%$ of per capita GDP. Our cost of abatement compares fairly well with those found in the literature, e.g., in McJeon et al. (2011). Although attaining the $2{ }^{\circ} \mathrm{C}$ goal comes at a price, the damages will be lower all along and the GDP growth better than for BAU starting from the 25 cross-over year 2058.

Recall, moreover, that the benefits of GHG abatement are not limited to the reduction of climate change costs alone. A reduction in $\mathrm{CO}_{2}$ emissions will often also reduce other environmental problems related to the combustion of fossil fuels (Van Den Bergh, 2015). Other co-benefits cover increased energy security (Jewell et al., 2016), increased agricultural production, and reduced pressure on ecosystems due to decreased tropospheric ozone concentrations (Pachauri, 2012). The

30 size of these so-called secondary benefits is site-dependent (IPCC, 1996b, p. 183), and we plan to take it into consideration in future versions of the CoCEB model. However, the attractiveness of mitigation measures has to be understood and quantified particularly by including co-benefits that are numerous and substantial (Pachauri, 2012; Rosen, 2016).

Table 4 gives a comparative summary of our CoCEB model's results and those from other studies that used more detailed IAM models and specific RCPs from IPCC (2013). We notice that the $\mathrm{CO}_{2}$ emissions per year and the concentrations in the

35 transition paths up to year 2100 agree fairly well with those of RCP8.5, RCP6.0 and RCP4.5, for $\tau_{\mathrm{b}}=0.0$ (BAU), 0.075 and 0.11 .

\section{Sensitivity analysis}

Most modelers are careful in specifying their BAU assumptions but they rarely report results from sensitivity analyses; see also Böhringer and Löschel (2004, p. 7) and Rosen (2016). We conducted an analysis to ascertain the robustness of the

40 CoCEB model's results and to clarify the degree to which they depend on three key parameters: the damage function 
parameters $m_{1}$ and $\chi$ and the abatement efficiency parameter $\alpha_{\tau}$. The values of these parameters are varied below in order to gain insight into the extent to which particular model assumptions affect our results in Sect. 3 above.

\subsection{Damage function parameters $m_{1}$ and $\chi$}

Considering the damage function of Eq. (20), the choice of the parameters $m_{1}>0$ and $\chi>0$ in the literature is ad hoc and

5 based on "informed guesses" (Peck and Teisberg, 1994). Clearly, the exponent $\chi$ is more important than the coefficient $m_{1}$, as the shape of the damage function varies from linear to cubic, $1 \leq \chi \leq 3$ (Ackerman et al., 2009), while $0.0022 \leq m_{1} \leq 0.0231$, cf. Roughgarden and Schneider (1999) and Labriet and Loulou (2003).

We modify the values of the parameters $m_{1}$ and $\chi$ by +50 and $-50 \%$ from their respective values of $m_{1}=0.0067$ and $\chi=2.43$ in Tables 1-4 above, so as to get their ranges into fair agreement with the ones in the literature, and examine how

10 that affects model results for year 2100. In Table 5 are listed the per annum $\mathrm{CO}_{2}$ emissions, $\mathrm{CO}_{2}$ concentrations, SAT, damages, and growth rate of per capita GDP. All parameter values are as in Table 1, including $\alpha_{\tau}=1.8$.

From Table 5, we notice that reducing $m_{1}$ by $50 \%$ lowers the damages at year 2100 to per capita GDP from $26.9 \%$ to $20.3 \%$, i.e. a $24.5 \%$ decrease for the BAU path. This damage reduction depresses the economy less and contributes to the $\mathrm{CO}_{2}$ emissions being higher, at $50.8 \mathrm{GtC} \mathrm{yr}^{-1}$. On the other hand, increasing $m_{1}$ by $50 \%$ increases the damages from $26.9 \%$

15 to $30.3 \%$, i.e. a $12.6 \%$ increase for the $\mathrm{BAU}$ path. This increase in damages depresses the economy more and lowers $\mathrm{CO}_{2}$ emissions in 2100 to $20.4 \mathrm{GtC}_{\mathrm{yr}^{-1}}$.

The sensitivity to the exponent $\chi$ is considerably higher. Decreasing it by $50 \%$ reduces the damages to per capita GDP from $26.9 \%$ to about $6.3 \%$, i.e. a $76.6 \%$ reduction for the BAU path. This reduction contributes to higher economic growth

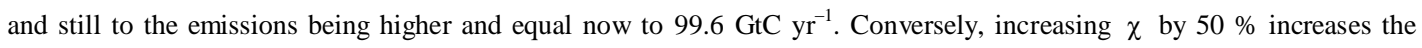

20 damages to per capita GDP from $26.9 \%$ to about $41.6 \%$, i.e. a $54.6 \%$ increase for the BAU path. This increase contributes

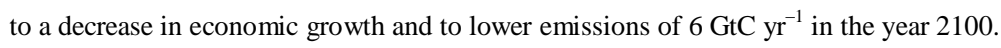

In Fig. 2, we plot the GDP growth in time for the experiments summarized in Table 5. It is clear from the figure that the growth rate of per capita GDP is more sensitive to the exponent $\chi$ than to the coefficient $m_{1}$. A decrease of $m_{1}$ by $50 \%$ pushes the crossover point further into the future, from year 2058 to 2070 (Fig. 2a), while an increase by $50 \%$ pulls the

25 crossover point closer to the present, to about 2053 (Fig. 2b). Decreasing $\chi$ by $50 \%$, on the other hand, pushes the crossover point even further away, past the end of the century (Fig. 2c), while an increase of $\chi$ by $50 \%$ pulls it from year 2058 to about 2037 (Fig. 2d).

\subsection{Abatement efficiency parameter $\alpha_{\tau}$}

Next, we modify the value of the parameter $\alpha_{\tau}$ by $+50 \%$ and $-50 \%$ from the standard value of $\alpha_{\tau}=1.8$ used in Tables 1-

305 above, and examine in Table 6 how that affects the model emissions reduction from BAU by the year 2100, as well as the per capita abatement costs and the per capita damage costs.

A $50 \%$ decrease of the abatement efficiency gives $\alpha_{\tau}=0.9$ in the upper half of the table. There is a substantial decrease in emissions reduction for all three scenarios with $\tau_{\mathrm{b}}>0$, compared to Table 3, and hence more damages for the same abatement costs. Furthermore, the increased damages increase the depression of the economy and contribute to low 35 economic growth.

On the other hand, a $50 \%$ increase in the abatement efficiency, to $\alpha_{\tau}=2.7$, leads to an increase in the emissions reduction from BAU by 2100 . This reduces the damages and hence lessens the depression to the economy, enabling economic growth to increase. 


\section{Conclusions, comparison to previous studies, and way forward}

\subsection{Summary}

In this paper, we introduce a simple coupled climate-economy (CoCEB) model with the goal of understanding the various feedbacks involved in the system and also for use by policy makers in addressing the climate change challenge. In this Part 1

5 of our study, economic activities are represented through a Cobb-Douglas output function with constant returns to scale of the two factors of production: per capita physical capital and per capita human capital. The income after tax is used for investment, consumption, and abatement.

Climate change enters the model through the emission of GHGs arising in proportion to economic activity. These emissions accumulate in the atmosphere and lead to a higher global mean surface air temperature (SAT). This higher

10 temperature then causes damages by reducing output according to a damage function. The CoCEB model, as formulated here, was summarized in Eqs. (22a)-(22e) in Sect. 2.6.

Using this model, we investigate in Sect. 3 the relationship between investing in the increase of overall energy efficiency of the economy and decrease of overall carbon intensity of the energy system through abatement activities. The time evolution, from 1990 to 2100, of the growth rate of the economy under threat from climate change-related damages is

15 likewise studied. The CoCEB model shows that taking no abatement measures to reduce GHGs leads eventually to a slowdown in economic growth; see also Kovalevsky and Hasselmann (2014, Fig. 2).

This slowdown implies that future generations will be less able to invest in emissions control or adapt to the detrimental impacts of climate change (Krakauer, 2014; Wagner and Weitzman, 2015). Therefore, the possibility of a long-term economic slowdown due to lack of abating climate change heightens the urgency of reducing GHGs by investing in low-

20 carbon technologies; see Xu et al. (2014) for innovative approaches towards low-carbon economics. Even if this incurs short-term economic costs, the transition to a de-carbonized economy is both feasible and affordable, according to Azar and Schneider (2002), Weber et al. (2005), Stern (2007), and would, in the long term, enhance economic growth and hence wealth (Hasselmann, 2010).

Few studies, though, focus on devising climate policy that aims to combine economic growth with emissions reductions

25 (Pielke, 2010, p. 66). The CoCEB model shows that an increase in the abatement share of investments can yield a win-win situation: higher annual economic growth rates, on average, of per capita GDP can go hand-in-hand with a decrease in GHG emissions and, as a consequence, with a decrease in average global SATs and in the ensuing damages; see also Greiner (2004), Greiner and Semmler (2008, pp. 95 and 120), and Sterner and Coria (2012, p. 154). These results hold when considering the entire transition path from now to 2100 , as a whole. Such a positive outcome's realization in practice

30 depends crucially, though, on the correctness of the functional relation between the economic damage and climate change assumed herein; see also Greiner (2004) and Greiner and Semmler (2008, p. 120).

\subsection{Comparison to previous studies}

The CoCEB model is a simplified version of the DICE 2013 model. The purpose of this simplification is to achieve greater flexibility and transparency. These features make it feasible to carry out systematic sensitivity studies and gain insight into 35 the importance of model assumptions in terms of achieving desirable policy goals.

We now compare CoCEB to the performance of the climate module in the models used in Clarke et al.'s (2014) assessment, such as the Model for the Assessment of Greenhouse-gas Induced Climate Change (MAGICC). MAGICC has been used in all IPCC Assessment reports, dating back to 1990. In particular, Working Group 1 of IPCC (2013) uses MAGICC for Projections of Global and Regional Climate Change (chapter 5), and DICE itself is calibrated to an earlier

40 version of the MAGICC model (Nordhaus, 2008, p. 54; Traeger, 2014). The climate model in MAGICC is an upwellingdiffusion model building on a hemispherically averaged energy balance equation. It models carbon uptake and warming 
feedbacks — both transient and long-run — in much greater detail than DICE's simple three-box linear carbon cycle and temperature delay equations (Nordhaus and Boyer, 2000).

CoCEB only endogenizes fossil fuel-based $\mathrm{CO}_{2}$ emissions. In contrast, MAGICC explicitly models the dynamics of a large set of GHGs. The IPCC's emission scenarios vary $\mathrm{CO}_{2}$ emissions, as well as the emission levels of other GHGs. Still,

5 our model represents fairly well the different RCP scenarios (see Tables 2 and 4), solely by adjusting endogenous $\mathrm{CO}_{2}$ emissions. Thus our highly simplified IAM replicates the responses to more comprehensive policy approaches regulating several GHGs just by endogenizing the main source of GHGs; see also Traeger (2014) for a further discussion.

The need for a hierarchy of models of increasing complexity is an idea that dates back in the climate sciences to the beginnings of numerical modeling (e.g., Schneider and Dickinson, 1974), and has been broadly developed and applied since

10 (Ghil, 2001, 2016, and references therein). The climate model hierarchy ranges from simple, conceptual ordinary differential equation (ODE) models (e.g., Rombouts and Ghil, 2015), like the one formulated and analyzed herein, through intermediate models of varying complexity (e.g., Claussen et al., 2002; Eby et al., 2009) and all the way up to full-scale general circulation models or global climate models (GCMs; e.g., Brönnimann, 2015, and references therein). There is an equivalent need for such a model hierarchy to deal with the higher-complexity problems at the interface of the physical climate sciences 15 and of socio-economic policy.

The CoCEB model and the results of this paper have to be viewed in the broader perspective of the hierarchy of climate models. CoCEB lies toward the highly idealized end of such a hierarchy. It cannot, nor does it claim to, represent the details of the real world. Simple models do not provide a quantitative description of the fully coupled dynamics of the real climateeconomy-biosphere system; on the other hand, though, the study of such models provides insights and makes it possible to

20 understand the qualitative mechanisms of the coupled-system processes and to evaluate their possible consequences. The role of the intermediate models is to refine these insights and bridge the gap between the simple models and the GCMs (Ghil, 2001; Claussen et al., 2002): on the one hand, they are still simple enough to allow a fairly thorough analysis of their behavior; on the other, they may be detailed enough for a direct comparison with the GCMs and with increasingly more plentiful and accurate observational data sets (see, e.g., Lu, 2015).

25 Moving from the climate module of IAMs to their economic module, we note that, in the DICE model, the economic costs associated with addressing and coping with climate warming are quantified by coupling a system of economic equations to an intermediate-complexity climate model. Given a variable-and-parameter space whose dimension is of the order of $19 \times 65$, the DICE model's outcome is an optimized trajectory for long-term societal welfare to which policy measures can be compared (Nordhaus and Sztorc, 2013).

30 The CoCEB model has 5 variables and 36 parameters. The dimension $5 \times 36$ of its variable-and-parameter space is thus considerably smaller than that of DICE. At the same time, CoCEB builds upon previous work on coupled models of global climate-economy interactions. It can thus be used to study not just one optimized trajectory, but a large variety of them, as well as their sensitivity to model assumptions and parameter values, while still maintaining a fairly reasonable degree of credibility.

35 CoCEB's year 2100 climate change damages before and after abatement range between 1.9-41.6 percent. Our model's damage values thus do agree fairly well with those in the literature; see, for instance, Creedy and Guest (2008).

For the damage function specifications of the DICE (Nordhaus, 2008), FUND (Anthoff et al, 2009) and PAGE (Hope, 2006) IAMs, however, even massive climate change damages have little effect on long-term economic growth; see, for instance, Wagner and Weitzman (2015). This common IAM feature may be explained by the Ramsey model of optimal

40 economic growth used as the basis for DICE, a model which assumes that economic growth is not limited by natural resources or environmental changes (Costanza et al., 2007).

Several other authors test alternative representations of climate damages (e.g., Ackerman et al, 2010), but all yield economies that grow even in the presence of large climate damages. The robustness of growth in these models suggests that 
their specification of climate damages may not reflect the full range of possible harms of climate change; see also Stern (2013), Wagner and Weitzman (2015), and Rosen (2016).

Technological change in CoCEB is modeled in a simple way by using logistic functions, in which growth depends on abatement investment. This is a novel approach with respect to most other IAM studies in the climate change mitigation

5 literature, in which technological change is assumed to be independent of public policy; see, for instance, the DICE (Nordhaus, 2007) and FOR-DICE (Eriksson, 2015) models, Tol's (2010) FUND and Van Vuuren et al.'s (2006a) IMAGE model.

While there clearly is room for improvement in our highly idealized CoCEB model, it is no worse in reproducing temperature responses for our set of emission scenarios than the RCP 8.0, 6.0 and 4.5 scenarios used in the most recent IPCC

10 Assessment Report (IPCC, 2013). The largest deviation in CoCEB from the IAMs reviewed by Clarke et al. (2014), e.g., MAGICC, occurs for our scenario corresponding to $\tau_{\mathrm{b}}=0.145$, the highest abatement share of the four.

\subsection{Way forward}

The CoCEB model, as developed in this first part of a two-part study, is sufficiently simple as to be transparent, to allow a range of sensitivity analyses, and to be available for a number of further extensions. The current model version analyzes the

15 carbon policy problem in a single-box global model with the aim of understanding theoretically the dynamic effects of using the abatement share as a climate change mitigation strategy. To be able to draw more concrete, quantitative policy recommendations is it important to account for regional disparities, an essential development left to future research.

The determination of an optimal set of abatement paths (Smirnov, 2005; Pivovarchuk, 2008) being the object of future work, we discuss here a number of improvements and extensions that will facilitate the formulation of the optimal control problem associated with the CoCEB model; see, for instance, Maurer et al. (2015).

Concerning first the damage function, Stern (2007) states that "Most existing IAMs also omit other potentially important factors - such as social and political instability and cross-sector impacts. And they have not yet incorporated the newest evidence on damaging warming effects," and he continues "A new generation of models is needed in climate science, impact studies and economics with a stronger focus on lives and livelihoods, including the risks of large-scale migration and 25 conflicts" (Stern, 2013, 2016).

Nordhaus and Sztorc (2013) suggest, more specifically, that the damage function needs to be reexamined carefully and possibly reformulated in cases of higher warming or catastrophic damages. Although there is considerable uncertainty surrounding climate-related damages, we find that, in our CoCEB model, assuming greater damages, via higher values of the exponent $\chi$, has the effect of advancing the crossover time, starting at which the abatement-related costs start paying off in

30 terms of increased per capita GDP growth. It seems, therefore, that it is compatible with better overall outcomes to assume a damage function that is more nonlinear.

A major drawback of current IAMs is that they mainly focus on mitigation in the energy sector (Van Vuuren et al., 2006b, p. 166) and mostly aim at reducing fossil fuel emissions. For example, the RICE and DICE (Nordhaus and Boyer, 2000) models consider emissions from deforestation as exogenous. Nevertheless, GHG emissions from deforestation and

35 current terrestrial uptake are significant and deserve greater attention for determining the potential of $\mathrm{CO}_{2}$ mitigation strategies; see Palmer and Engel (2009), Ciais et al. (2013), Scott (2014), and references therein. Several studies provide evidence that forest carbon sequestration can help reduce atmospheric $\mathrm{CO}_{2}$ concentration significantly and in a cost-efficient way (e.g., Bosetti et al., 2011).

In Part 2 of this paper, we report on work along these lines, by introducing a biosphere module into CoCEB. This model

40 version allows us to study relevant economic aspects of deforestation control and carbon sequestration in forests, as well as the widespread application of CCS technologies as alternative policy measures for climate change mitigation. Moreover, in order to understand the dynamic role of energy production and consumption in this broader context, we also plan to extend 
the CoCEB model by introducing energy as a production factor that can be substituted by labor and capital, which is not the case in most IAMs; see also Garrett (2015, and references therein).

Finally, current IAMs disregard endogenous variability and represent both climate and the economy as a succession of equilibrium states with no endogenous dynamics. This shortcoming can be overcome by introducing business cycles into the

5 economic module (e.g., Chiarella et al., 2005, and references therein; Akaev, 2007; Hallegatte et al., 2008; Grasselli and Huu, 2015) and by taking them into account in considering the impact of natural, climate-related, as well as purely economic shocks (Hallegatte and Ghil, 2008; Groth et al., 2016).

\section{Appendix A: Abatement policies}

Although it is questionable how quickly the energy system could be transformed (Smil, 2010), GHG mitigation strategy

10 proposals call for major, and relatively rapid, changes in the global energy system (Barker and Jenkins, 2007; Miller, 2013). For reasons of political feasibility as well as of efficiency, the focus of climate policy has been on energy intensity and carbon intensity of energy, and not on population and wealth (Pielke, 2010, p. 109; Tol, 2010; Miller, 2013). All the popular policies point to increased de-carbonization efforts, i.e. to an increase in $g_{\sigma}$. The historical record, however, shows quite clearly that global and regional rate of de-carbonization have seen no acceleration during the recent decade and in some

15 cases even show evidence of re-carbonization (Prins et al., 2009; Garrett, 2015). This situation is inconsistent with a path of keeping $T$ below $2{ }^{\circ} \mathrm{C}$ over pre-industrial levels, and poses the risk of humanity's having to confront policy-relevant climatic shifts in the 21st century (Richardson et al., 2011, p. 163; Rockström et al., 2015) that could lead to potentially irreversible and unpredictable dynamical interactions (Rydge and Bassi, 2014).

When the costs of reducing emissions vary greatly between different entities (as they do for GHG emissions), market-

20 based (economic) instruments are likely to be more efficient compared to command-and-control regulation (Baumol and Oates, 1971, 1988). Among the various economic instruments adopted to reduce $\mathrm{CO}_{2}$ emissions, carbon taxes and tradable permits - as well as various hybrids of the two (Hepburn, 2010) - are the most widely discussed cost-efficient policies, both at a national and international level (Uzawa, 2003; Böhringer and Lange, 2005; Pizer, 2006; Nordhaus, 2008; Edenhofer et al., 2015). Both approaches provide incentives for producers and consumers to reduce emissions, and both

25 should stimulate behavioral and technological change to conserve energy, or produce it from renewable sources (Dryzek et al., 2013, p. 59). Sometimes, neither permits nor taxes can be used, and the lack of information, uncertainty as well as the asymmetric information problems can make policy design quite complicated (Sterner and Coria, 2012, p. 163). Hence the need of having flexible and transparent model results to guide policy makers.

Forestry policies, particularly deforestation control, also emerge as additional low cost measures for the reduction of $\mathrm{CO}_{2}$

30 emissions (see also, Sohngen, 2010). Deforestation control would cut $\mathrm{CO}_{2}$ emissions and increased afforestation would sequester $\mathrm{CO}_{2}$ from the atmosphere (see, e.g., Bosetti et al., 2011; Scott, 2014). However, one should not be too quick to reach general conclusions about which type of instrument is best suited. Choices should be made carefully, on a case-by-case basis (Sterner and Coria, 2012, p. 7), and follow-up on the present paper and Part 2 will bring in this approach into the CoCEB model in order to help decision makers.

35 Competing interests. The authors declare that they have no conflict of interest.

Acknowledgements. This work was supported by the Energy and Prosperity Chair of the Fondation du Risque, Paris, and by Dedan Kimathi University of Technology (DeKUT), whose views it does not claim to represent. It is a pleasure to thank Hermann Held, Axel Kleidon and two anonymous reviewers for thoughtful and constructive comments that contributed to improve an earlier version of this manuscript. The CoCEB model code is available from the authors upon request. 


\section{References}

Abdussamatov, H. I.: The New Little Ice Age Has Started, in: Evidence-Based Climate Science: Data Opposing $\mathrm{CO}_{2}$ Emissions as the Primary Source of Global Warming, 2nd Edn., edited by Easterbrook, D. J., Elsevier, Amsterdam, Oxford, pp. 307-328, 2016.

Ackerman, F., Stanton, E. A., and Bueno, R.: Fat tails, exponents, extreme uncertainty: Simulating catastrophe in DICE, Ecol. Econ., 69, 1657-1665, 2010.

Ackerman, F., Stanton, E. A., Hope, C., and Alberth, S.: Did the Stern Review underestimate US and global climate damages? Energ. Policy, 37, 2717-2721, 2009.

Akaev, A. A.: Derivation of the general macroeconomic dynamics equation describing the joint interaction of longterm growth and business cycles, Dokl. Math., 76, 879-881, 2007.

Akaev, A. A.: Stabilization of Earth's climate in the 21 st century by the stabilization of per capita consumption, in: The Oxford Handbook of the Macroeconomics of Global Warming, edited by: Bernard, L. and Semmler, W., Oxford University Press, New York, NY, USA, pp. 499-554, 2015.

Anthoff, D., Tol, S. J. R., and Yohe, G. W.: Risk aversion, time preference, and the social cost of carbon, Environ. Res. Lett., 4, 1-7, 2009.

Azar, C. and Schneider, S. H.: Are the economic costs of stabilizing the atmosphere prohibitive?, Ecol. Econ., 42, 73-80, 2002.

Barker, T. and Jenkins, K.: The costs of avoiding dangerous climate change: Estimates derived from a meta-analysis of the literature, A briefing paper for the United Nations Human Development Report 2007, contract No. 40015, Cambridge Centre for Climate Change Mitigation Research (4CMR), University of Cambridge, Cambridge, UK, 2007.

Barker, T., Ekins, P. and Johnstone, N.: Global Warming and Energy Demand, Routledge, London, UK, and New York, NY, USA, 281 pp., 1995.

Barron, R. and McJeon, H.: The differential impact of low-carbon technologies on climate change mitigation cost under a range of socioeconomic and climate policy scenarios, Energ. Policy, 80, 264-274, 2015.

Bauer, N.: Carbon capturing and sequestration - an option to buy time, PhD thesis, Faculty of Economics and Social Sciences, University Potsdam, Potsdam, Germany, 336 pp., 2005.

Baumol, W. J. and Oates, W. E.: The use of standards and prices for protection of the environment, in: The Economics of Environment: Papers from Four Nations, edited by: Bohm, P., and Kneese, A. V., Palgrave Macmillan, London and Basingstoke, UK, pp. 53-65, 1971.

Baumol, W. J. and Oates, W. E.: The Theory of Environmental Policy, 2nd Edn., Cambridge University Press, New York, NY, USA, 299 pp., 1988.

Bickel, J. E. and Lane, L.: Climate engineering, in: Smart Solutions to Climate Change: Comparing Costs and Benefits, edited by: Lomborg, B., Cambridge University Press, New York, NY, USA, pp. 9-51, 2010.

Böhringer, C. and Löschel, A. (Eds.): Climate Change Policy and Global Trade, Springer, Berlin, Heidelberg, Germany, 386 pp., 2004.

Böhringer, C. and Lange, A. (Eds.): Applied Research in Environmental Economics, Physica-Verlag, Heidelberg, Germany, 314 pp., 2005.

Bosetti, V., Lubowski, R., Golub, A., and Markandya, A.: Linking reduced deforestation and global carbon market: Implications for clean energy technology and policy flexibility, Environ. Dev. Econ., 16, 479-505, 2011.

Bowen, A.: The scope for "green growth" and a new technological revolution, in: The Global Development of 
Earth Syst. Dynam. Discuss., doi:10.5194/esd-2016-64, 2017

Manuscript under review for journal Earth Syst. Dynam.

Published: 17 January 2017

(c) Author(s) 2017. CC-BY 3.0 License.

Policy Regimes to Combat Climate Change, edited by: Stern, N. H., Bowen, A., and Whalley, J., World Scientific Publ. Co., Singapore, pp. 133-155, 2014.

Bréchet, T., Camacho, C., and Veliov, V. M.: Adaptive model-predictive climate policies in a multicountry setting, in: The Oxford Handbook of the Macroeconomics of Global Warming, edited by: Bernard, L. and Semmler, W., Oxford University Press, New York, NY, USA, pp. 114-138, 2015.

Brock, W. A. and Xepapadeas, A.: Modeling coupled climate, ecosystems, and economic systems, Department of International and European Economic Studies, Athens University of Economics and Business, Working Paper Series 15-08, 2015.

Brock, W.A., Xepapadeas, A., and Yannacopoulos, A. N.: Optimal control in space and time and the management of environmental resources, Annu. Rev. Resour. Economics, 6, 33-68, 2014.

Brönnimann, S.: Climatic Changes Since 1700, Springer, Switzerland, 373 pp., 2015.

Calvin, K., Edmonds, J., Bond-Lamberty, B., Clarke, L., Kim, S. H., Kyle, P., Smith, S. J., Thomson, A., and Wise, M.: 2.6: Limiting climate change to $450 \mathrm{ppm} \mathrm{CO}_{2}$ equivalent in the 21 st century, Energ. Econ., 31, 107120, 2009.

Chang, C.-P., Ghil, M., Latif, M., and Wallace, J. M. (Eds.): Climate Change: Multidecadal and Beyond, World Scientific Publ. Co./Imperial College Press, Singapore, 388 pp., 2016.

Charney, J. G., Arakawa, A., Baker, D. J., Bolin, B., Dickinson, R. E., Goody, R. M., Leith, C. E., Stommel, H. M., and Wunsch, C. I.: Carbon Dioxide and Climate: A Scientific Assessment, National Academic Press, Washington, DC, USA, 22 pp., 1979.

Chen, W.-Y., Seiner, J., Suzuki, T., and Lackner, M. (Eds.): Handbook of Climate Change Mitigation, Springer, New York, NY, USA, 2158 pp., 2012.

Chiarella, C., Flaschel, P., and Franke, R.: Foundations for a Disequilibrium Theory of the Business Cycle: Qualitative Analysis and Quantitative Assessment, Cambridge University Press, New York, NY, USA, 2005.

Ciais, P., Gasser, T., Paris, J. D., Caldeira, K., Raupach, M. R., Canadell, J. G., Patwardhan, A., Friedlingstein, P., Piao, S. L., and Gitz, V.: Attributing the increase in atmospheric $\mathrm{CO}_{2}$ to emitters and absorbers, Nat. Clim. Change, 3, 926-930, 2013.

Clarke, L., Jiang, K., Akimoto, K., Babiker, M., Blanford, G., Fisher-Vanden, K., Hourcade, J.-C., Krey, V., Kriegler, E., Löschel, A., McCollum, D., Paltsev, S., Rose, S., Shukla, P. R., Tavoni, M., Van der Zwaan, B. C. C., and Van Vuuren, D. P.: Assessing Transformation Pathways, in: Climate Change 2014: Mitigation of Climate Change, Contribution of Working Group 3 to the Fifth Assessment Report of the Intergovernmental Panel on Climate Change, edited by: Edenhofer, O., Pichs Madruga, R., Sokona, Y., Farahani, E., Kadner, S., Seyboth, K., Adler, A., Baum, I., Brunner, S., Eickemeier, P., Kriemann, B., Savolainen, J., Schlömer, S., Von Stechow, C., Zwickel, T. and Minx, J. C., Cambridge University Press, Cambridge, United Kingdom \& New York, NY, USA, 2014.

Claussen, M., Mysak, L. A., Weaver, A. J., Crucifix, M., Fichefet, T., Loutre, M. F., Weber, S. L., Alcamo, J., Alexeev, V. A., Berger, A., Calov, R., Ganopolski, A., Goosse, H., Lohman, G., Lunkeit, F., Mokhov, I. I., Petoukhov, V., Stone, P., and Wang, Z.: Earth system models of intermediate complexity: Closing the gap in the spectrum of climate system models, Clim. Dynam., 18, 579-586, 2002.

Cobb, C. W. and Douglas, P. H.: A theory of production, Am. Econ. Rev., 18, 139-165, 1928.

Costanza, R., Leemans, R., Boumans, R. M. J., and Gaddis, E.: Integrated Global Models, in: Sustainability or Collapse?: An Integrated History and Future of People on Earth, Report of the 96th Dahlem Workshop on Integrated History and future Of People on Earth (IHOPE) Berlin, June 12-17, 2005, edited by: Costanza, 
R., Graumlich, L. J., and Steffen, W., Massachusetts Institute of Technology and Freie Universität Berlin, Cambridge, MA, UK, 417-446, 2007.

Creamer, A. E. and Gao, B.: Carbon Dioxide Capture: An Effective Way to Combat Global Warming, Springer, Cham, Heidelberg, New York, Dordrecht, London, 62 pp., 2015.

Creedy, J. and Guest, R.: Sustainable preferences and damage abatement: Value judgments and implications for consumption streams, Research Paper 1026, Department of Economics, University of Melbourne, Melbourne, Australia, 2008.

De Vries, B. J. M.: Scenarios guidance for an uncertain and complex world?, in: Sustainability or Collapse?: An Integrated History and Future of People on Earth, Report of the 96th Dahlem Workshop on Integrated History and future Of People on Earth (IHOPE) Berlin, June 12-17, 2005, edited by: Costanza, R., Graumlich, L. J., and Steffen, W., Massachusetts Institute of Technology and Freie Universität Berlin, Cambridge, MA, UK, 379-397, 2007.

DeCanio, S. J.: Economic Models of Climate Change: A Critique, Palgrave Macmillan, New York, NY, USA, 218 pp., 2003.

DDPP (Deep Decarbonization Pathways Project): Pathways to deep decarbonization 2015 report, Sustainable Development Solutions Network (SDSN) \& Institute for Sustainable Development and International Relations (IDDRI), 2015.

Dell, M., Jones, B. F., and Olken, B. A.: What do we learn from the weather? The new climate economy literature, J. Econ. Lit., 52, 740-798, 2014.

Diesendorf, M.: Redesigning Energy Systems, in: The Oxford Handbook of Climate Change and Society, edited by: Dryzek, J. S., Norgaard, R. B., and Schlosberg, D., Oxford University Press, New York, NY, USA, 561-579, 2012.

Diesendorf, M.: Sustainable Energy Solutions for Climate Change Mitigation, University of New South Wales Press Ltd, Sydney, Australia, 142-143, 2014.

Dong, W., Ren, F., Huang, J., and Guo, Y.: The Atlas of Climate Change: Based on SEAP-CMIP5: Super-Ensemble Projection and Attribution (SEAP) of Climate Change, Springer, Berlin, Heidelberg, Germany, 210 pp., 2013.

Dryzek, J. S., Norgaard, R. B., and Schlosberg, D.: Climate-Challenged Society, Oxford University Press, New York, NY, USA, 193 pp., 2013.

Eby, M., Zickfeld, K., Montenegro, A., Archer, D., Meissner, K. J., and weaver, A. J.: Lifetime of anthropogenic climate change: Millennial time scales of potential $\mathrm{CO}_{2}$ and surface temperature perturbations, J. Climate, 22, 2501-2511, 2009.

Edenhofer, O., Flachsland, C., Jakob, M., and Lessmann, K.: The atmosphere as a global commons: Challenges for international cooperation and governance, in: The Oxford Handbook of the Macroeconomics of Global Warming, edited by: Bernard, L. and Semmler, W., Oxford University Press, New York, NY, USA, pp. 260-296, 2015.

Edenhofer, O., Carraro, C., and Hourcade, J. C.: On the economics of de-carbonization in an imperfect world, Climatic Change, 114, 1-8, 2012.

Edmonds, J., Joos, F., Nakićenović, N., Richels, R. G., and Sarmiento, J. L.: Scenarios, Targets, Gaps, and Costs, in: The Global Carbon Cycle: Integrating Humans, Climate, and the Natural World, edited by Field, C. B. and Raupach, M. R., Scientific Committee on Problems of the Environment (SCOPE) 62, Island Press, Paris, France, 2004.

Edmonds, J., Luckow, P., Calvin, K., Wise, M., Dooley, J., Kyle, P., Kim, S. H., Patel, P., and Clarke, L.: Can 
radiative forcing be limited to $2.6 \mathrm{Wm}^{-2}$ without negative emissions from bioenergy and $\mathrm{CO}_{2}$ capture and storage?, Climatic Change, 118, 29-43, 2013.

Eriksson, M.: The role of the forest in an integrated assessment model of the climate and the economy, Climate Change Economics, 6:1550011, 1-29, 2015.

Erk, N., Çabuk, A., and Ateş, S.: Long-run growth and physical capital-human capital concentration, METU International Economic Conference II, 9-12 September 1998, Ankara, 1998.

Flavi, C. and Engelman, R.: The perfect storm, in: 2009 State of the World: Into a Warming World, Worldwatch Institute, 5-12, 2009.

Fraedrich, K., Bordi, I., and Zhu, X.: Climate dynamics on global scale: Resilience, hysteresis and attribution of change, in: The Fluid Dynamics of Climate, edited by: Provenzale, A., Palazzi, E., and Fraedrich, K., Springer, Udine, Italy, 143-159, 2016.

Friedlingstein, P., Houghton, R. A., Marland, G., Hackler, J., Boden, T. A., Conway, T. J., J. Canadell, J. G., Raupach, M. R., Ciais, P. and Le Quéré, C.: Update on $\mathrm{CO}_{2}$ emissions, Nat. Geosci., 3, 811-812, 2010.

Garrett, T. J.: No way out? The double-bind in seeking global prosperity alongside mitigated climate change, Earth Syst. Dynam., 3, 1-17, 2012.

Garrett, T. J.: Long-run evolution of the global economy - Part 2: Hindcasts of innovation and growth, Earth Syst. Dynam., 6, 673-688, 2015.

Gerlagh, R. and Van der Zwaan, B.: Gross world product and consumption in a global warming model with endogenous technological change, Resour. Energ. Econ., 25, 35-57, 2003.

Ghil, M.: Hilbert problems for the geosciences in the 21st century, Nonlinear Proc. Geoph., 8, 211-222, 2001.

Ghil, M.: A mathematical theory of climate sensitivity or, How to deal with both anthropogenic forcing and natural variability?, Ch. 2 in Climate Change: Multidecadal and Beyond, edited by: Chang, C. P., Ghil, M., Latif, M., and Wallace, J. M., World Scientific Publ. Co./Imperial College Press, pp. 31-51, 2016.

Ghil, M. and Childress, S.: Topics in Geophysical Fluid Dynamics: Atmospheric Dynamics, Dynamo Theory and Climate Dynamics, Springer, NY/Berlin/Tokyo, 1987.

Glotter, M. J., Pierrehumbert, R. T., Elliott, J. W., Matteson, N. J., and Moyer, E. J.: A simple carbon cycle representation for economic and policy analyses, Climatic Change, 126, 319-335, 2014.

Gollin, D.: Getting income shares right, J. Polit. Econ., 110, 458-474, 2002.

Golosovsky, M.: Hyperbolic growth of the human population of the Earth: Analysis of existing models, in: History and Mathematics: Processes and Models of Global Dynamics, edited by: Grinin, L., Herrmann, P., Korotayev, A., and Tausch, A., Uchitel, Volgograd, Russia, 188-204, 2010.

Grasselli, M. R. and Huu, A. N.: Inflation and speculation in a dynamic macroeconomic model, J. Risk Financial Manag., 8, 285-310, 2015.

Greiner, A.: Anthropogenic climate change in a descriptive growth model, Environ. Dev. Econ., 9, 645-662, 2004.

Greiner, A.: Climate change and second-best abatement in a multiregion world with endogenous growth, in: The Oxford Handbook of the Macroeconomics of Global Warming, edited by: Bernard, L. and Semmler, W., Oxford University Press, New York, NY, US A, 204-221, 2015.

Greiner, A. and Semmler, W.: The Global Environment, Natural Resources and Economic Growth, Oxford University Press, New York, NY, 60-68, 2008.

Grinin, L. and Korotayev, A.: Great Divergence and Great Convergence: A Global Perspective, Springer, Switzerland, 261 pp., 2015.

Groth, A., Dumas, P., Ghil, M., and Hallegatte, S.: Impacts of natural disasters on a dynamic economy, in: Extreme Events: Observations, Modeling and Economics, edited by: Chavez, M., Ghil, M., and Urrutia-Fucugauchi, 
Earth Syst. Dynam. Discuss., doi:10.5194/esd-2016-64, 2017

Manuscript under review for journal Earth Syst. Dynam.

Published: 17 January 2017

(c) Author(s) 2017. CC-BY 3.0 License.

J., Geophysical Monograph 214, American Geophysical Union \& Wiley, Washington, DC, USA, pp. 343-359, 2016.

Guest, R.: The economics of sustainability in the context of climate change: An overview, J. World Bus., 45, 326$335,2010$.

Gueymard, C.: The Sun's total and spectral irradiance for solar energy applications and solar radiation models, Sol. Energy, 76, 423-452, 2004.

Hallegatte, S. and Ghil, M.: Natural disasters impacting a macroeconomic model with endogenous dynamics, Ecol. Econ., 68, 582-592, 2008.

Hallegatte, S., Ghil, M., Dumas, P., and Hourcade, J. C.: Business cycles, bifurcations and chaos in a neoclassical model with investment dynamics, J. Econ. Behav. Organ., 67, 57-77, 2008.

Hannart, A., Ghil, M., Dufresne, J.-L., and Naveau, P.: Disconcerting learning on climate sensitivity and the uncertain future of uncertainty, Climatic Change, 119, 585-601, 2013.

Hans, G. K. and Hans, E.: Mathematics and Climate, Society for Industrial and Applied Mathematics (SIAM), Philadelphia, Pennsylvania, USA, 318 pp., 2013.

Hasselmann, K.: The climate change game, Nat. Geosci., 3, 511-512, 2010.

Hay, W. W.: Experimenting on a Small Planet, Springer, Berlin, Heidelberg, Germany, 998 pp., 2013.

Held, H., Kriegler, E., Lessmann, K., and Edenhofer, O.: Efficient climate policies under technology and climate uncertainty, Energ. Econ., 31, S50-S61, 2009.

Hepburn, C.: Carbon Taxes, Emissions Trading, and Hybrid Schemes, in: The Economics and Politics of Climate Change, edited by: Helm, D. and Hepburn, C., Oxford University Press, New York, NY, US A, 365-384, 2010.

Hijioka, Y., Matsuoka, Y., Nishomoto, H., Masui, M., and Kainuma, M.: Global GHG emission scenarios under GHG concentration stabilization targets, J. Global Environ. Eng., 13, 97-108, 2008.

Hope, C.: The marginal impact of $\mathrm{CO}_{2}$ from PAGE2002: An integrated assessment model incorporating the IPCC's five reasons for concern, IAJ, 6, 19-56, 2006.

Hüsler, A. D. and Sornette, D.: Human population and atmospheric carbon dioxide growth dynamics: Diagnostics for the future, Eur. Phys. J-Spec. Top., 223, 2065-2085, 2014.

Idso, C. D., Carter R. M., and Singer, S. F. (Eds.): Climate Change Reconsidered II: Physical Science, The Heartland Institute, Chicago, Illinois, USA, 868 pp., 2013.

IPCC: Climate Change 1995: The Science of Climate Change, Contribution of Working Group I to the Second Assessment Report of the IPCC, Cambridge University Press, Cambridge, 588 pp., 1996 a.

IPCC: Climate Change 1995: Economic and Social Dimensions of Climate Change, Contribution of Working Group III to the Second Assessment Report of the IPCC, edited by: Bruce, J. P., Lee, H., and Haites, E. F., Cambridge University Press, Cambridge, 438 pp., 1996 b.

IPCC: Climate Change 2001: The Scientific Basis, Contribution of Working Group I to the Third Assessment Report of the IPCC, edited by: Houghton, J. T., Ding, Y., Griggs, D. J., Noguer, M., Van der Linden, P. J., Dai, X., Maskell, K., and Johnson, C. A., Cambridge University Press, Cambridge, 881 pp., 2001.

IPCC: Climate Change 2007: The Physical Science Basis. Contribution of Working Group I to the Fourth Assessment Report of the IPCC, edited by: Solomon, S., Qin, D., Manning, M., Chen, Z., Marquis, M., Averyt, K., Tignor, M. M. B., Miller Jr., H. L., and Chen, Z., Cambridge University Press, Cambridge, 1206 pp., 2007a.

IPCC: Contribution of Working Groups I, II and III to the Fourth Assessment Report of the Intergovernmental Panel on Climate Change, Cambridge University Press, Cambridge, 2007b. 
IPCC: Summary for Policymakers, in: Climate Change 2007: Mitigation. Contribution of Working Group III to the Fourth Assessment Report of the IPCC, edited by: Metz, B., Davidson, O. R., Bosch, P. R., Dave, R., and Meyer, L. A., Cambridge University Press, Cambridge, United Kingdom \& New York, NY, USA, 2007c.

IPCC: Climate Change 2013: The Physical Science Basis, Contribution of Working Group I to the Fifth Assessment Report of the IPCC, edited by: Stocker, T. F., Qin, D., Plattner, G.- K., Tignor, M., Allen, S. K., Boschung, J., Nauels, A., Xia, Y., Bex, V., and Midgley, P. M., Cambridge University Press, 1535 pp., 2013.

Jewell, J., Vinichenko, V., McCollum, D., Bauer, N., Riahi, K., Aboumahboub, T., Fricko, O., Harmsen, M., Kober, T., Krey, V., Marangoni, G., Tavoni, M., Van Vuuren, D. P., Van der Zwaan, B., and Cherp, A.: Comparison and interactions between the long-term pursuit of energy independence and climate policies, Nature Energ., 1, 1-9, 2016.

Kaya, Y.: Impact of carbon dioxide emission control on GNP growth: Interpretation of proposed scenarios, Paper presented to the IPCC Energy and Industry Subgroup, Response Strategies Working Group, Paris, 1990.

Kemfert, C.: An integrated assessment model of economy-energy-climate - the model Wiagem, Integrat. Ass., 3, 281-298, 2002.

Kovalevsky, D. V. and Hasselmann, K.: Assessing the transition to a low-carbon economy using actor-based system-dynamic models, in: Proceedings of the 7th International Congress on Environmental Modeling and Software (iEMSs), edited by: Ames, D. P., Quinn, N. W. T., and Rizzoli, A. E., 15-19 June 2014, San Diego, California, USA, 1865-1872, available at: http: //www.iemss.org/society/index.php/iemss-2014proceedings (last access: 5 October 2014), 2014.

Krakauer, N. Y.: Economic growth assumptions in climate and energy policy, Sustainability, 6, 1448-1461, 2014.

Kriegler, E., Weyant, J., Blanford, G. J., Krey, V., Clarke, L., Edmonds, J., Fawcett, A., Luderer, G., ～Riahi, $\quad$ K., Richels, R. G., Rose, S., Tavoni, M., and Van Vuuren, D. P.: The role of technology for achieving climate policy objectives: Overview of the EMF 27 study on global technology and climate policy strategies, Climatic Change, 123, 353 - 367, 2014.

Kuckshinrichs, W. and Hake, J.-F. (Eds.): Carbon Capture, Storage and Use: Technical, Economic, Environmental and Societal Perspectives, Springer, Switzerland, 352 pp., 2015.

Labriet, M. and Loulou, R.: Coupling climate damages and GHG abatement costs in a linear programming framework, Environ. Model. Assess., 8, 261-274, 2003.

Lenton, T. M.: Land and ocean carbon cycle feedback effects on global warming in a simple Earth system model, Tellus B, 52, 1159-1188, 2000.

Levitus, S., Antonov, J., and Boyer, T.: Warming of the world ocean, 1955-2003, Geophys. Res. Lett., 32, L02604, 2005.

Lu, Q.-B.: New Theories and Predictions on the Ozone Hole and Climate Change, World Scientific Publ. Co., Singapore, 308 pp., 2015.

Maurer, H., Preuß, J. J., and Semmler, W.: Policy scenarios in a model of optimal economic growth and climate change, in: The Oxford Handbook of the Macroeconomics of Global Warming, edited by: Bernard, L. and Semmler, W., Oxford University Press, New York, NY, US A, pp. 82-113, 2015.

McGuffie, K. and Henderson-Sellers, A.: A Climate Modeling Primer, 3rd Edn., Wiley, Chichester, England, UK, 287 pp., 2005.

Metz, B., Davidson, O. R., Bosch, P. R., Dave, R., and Meyer, L. A. (Eds.): Climate Change 2007: Mitigation of Climate Change, Contribution of Working Group III to the Fourth Assessment Report of the IPCC, Cambridge University Press, Cambridge, United Kingdom \& New York, NY, USA, 863 pp., 2007.

Meyers, R. A. (Ed.): Encyclopedia of Sustainability Science and Technology, Springer, New York, Dordrecht, 
Heidelberg, London, 12678 pp., 2012.

Miller, C. A.: Energy resources and policy: Vulnerability of energy resources and resource availability - fossil fuels (oil, coal, natural gas, oil shale), in: Climate Vulnerability Understanding and Addressing Threats to Essential Resources, Volume 3: Vulnerability of Energy to Climate, edited by: Pielke Sr., R. A., Adegoke, J., Wright, C.Y., Niyogi, D., Kallos, G., Seastedt, T., Suding, K., Hossain, F., Academic Press, Oxford, UK, pp. 518-532, 2013.

Mokhov, I. I., Smirnov, D. A., and Karpenko, A. A.: Assessments of the relationship of changes of the global surface air temperature with different natural and anthropogenic factors based on observations, Dokl. Earth Sci., 443, 381-387, 2012.

Moyer, E. J., Woolley, M. D., Glotter, M. J., and Weisbach, D. A.: Climate impacts on economic growth as drivers of uncertainty in the social cost of carbon, The University of Chicago, Coase-Sandor Institute for Law and Economics Working Paper no. 652, 2013.

Nakićenović, N. and Swart, R. J. (Eds.): IPCC Special Report on Emissions Scenarios, Cambridge University Press, Cambridge, UK, 608 pp., 2000.

Nordhaus, W. D.: Managing the Global Commons: The Economics of Climate Change, MIT Press, Cambridge, 1994a.

Nordhaus, W. D.: Expert opinion on climatic change, Am. Sci., 82, 45-51, 1994b.

Nordhaus, W. D.: The Challenge of Global Warming: Economic Models and Environmental Policy, Yale University Press, New Haven, CT, USA, 253 pp., 2007.

Nordhaus, W. D.: A Question of Balance: Weighing the Options on Global Warming Policies, Yale University Press, New Haven, CT, USA, 249 pp., 2008.

Nordhaus, W. D. and Boyer, J.: Warming the World: Economic Models of Global Warming, MIT Press, Cambridge, MA, 245 pp., 2000.

Nordhaus, W. D. and Sztorc, P.: DICE 2013R: Introduction and User's Manual, 2nd Edn., available at: www.econ.yale.edu/ nordhaus/homepage/documents/DICE2013R_Manual_2ndEd.pdf (last access: 6 October 2013), 2013.

Ortiz, R. A. and Markandya, A.: Integrated impact assessment models of climate change: A literature review, BC3 Working Paper Series, 2009-06, 2009.

Pachauri, R. K.: The way forward in climate change mitigation, WIREs Energy Environ., 1, 3-8, 2012.

Palmer, C. \& Engel, S. (Eds.) Avoided Deforestation: Prospects for Mitigating Climate Change, Routledge Explorations in Environmental Economics, Routledge, London, UK \& New York, USA, 273 pp., 2009.

Palmer, G.: Does energy efficiency reduce emissions and peak demand? A case study of 50 years of space heating in Melbourne, Sustainability, 4, 1525-1560, 2012.

Peck, S. C. and Teisberg, T. J.: Optimal carbon emissions trajectories when damages depend on the rate or level of global warming, Climatic Change, 28, 289-314, 1994.

Pielke Jr., R. A.: The Climate Fix: What Scientists and Politicians Won't Tell You About Global Warming, Basic Books, New York, NY, USA, 290 pp., 2010.

Pielke Jr., R. A., Wigley, T. M. L., and Green, C.: Dangerous assumptions, Nature, 452, 531-532, 2008.

Pindyck, R. S.: Climate change policy: What do the models tell us?, J. Econ. Lit., 51, 860-872, 2013.

Pivovarchuk, D.: Consistency between Long-term Climate Target and Short-term Abatement Policy, IIASA Interim Report, IR-08-017, 2008.

Pizer, W. A.: Choosing price or quantity controls for greenhouse gases, in: The RFF Reader in Environmental and Resource Policy, 2nd Edn., edited by: Oates, W. E., Resources for the Future Press, Washington, DC, 
Earth Syst. Dynam. Discuss., doi:10.5194/esd-2016-64, 2017

Manuscript under review for journal Earth Syst. Dynam.

Published: 17 January 2017

(c) Author(s) 2017. CC-BY 3.0 License.

USA, 225-234, 2006.

Prins, G., Cook, M., Green, C., Hulme, M., Korhola, A., Korhola, E.-R., Pielke, Jr. R. A., Rayner, S., Sawa, A., Sarewitz, D., Stehr, N., and Von Storch, H.: How to get climate policy back on course, Institute for Science, Innovation and Society, University of Oxford, Oxford, UK, 15 pp., 2009.

Riahi, K., Gruebler, A., and Nakićenović, N.: Scenarios of long-term socio-economic and environmental development under climate stabilization, Technol. Forecast. Soc. Change, 74, 887-935, 2007.

Richardson, K., Steffen, W., Liverman, D., Barker, T., Jotzo, F., Kammen, D. M., Leemans, R., Lenton, T. M., Munasinghe, M., Osman-Elasha, B., Schellnhuber, H. J., Stern, N. H., Vogel, C., and Wæver, O.: Climate Change: Global Risks, Challenges and Decisions, Cambridge University Press, New York, NY, USA, 541 pp., 2011.

Rockström, J., Klum, M., and Miller, P.: Big World, Small Planet: Abundance Within Planetary Boundaries, Yale University Press, New Haven, USA, \& London, UK, 208 pp., 2015.

Rogelj, J., Luderer, G., Pietzcker, R. C., Kriegler, E., Schaeffer, M., Krey, V. and Riahi, K.: Energy system transformations for limiting end-of-century warming to below $1.5{ }^{\circ} \mathrm{C}$, Nat. Clim. Change, 5, 519-528, 2015.

Rombouts, J. and Ghil, M.: Oscillations in a simple climate-vegetation model, Nonlinear Proc. Geoph., 22, 275$288,2015$.

Romer, D.: Advanced Macroeconomics, 4th Edn., McGraw-Hill, New York, NY, USA, 738 pp., 2012.

Rosen, R. A.: Is the IPCC's 5th assessment a denier of possible macroeconomic benefits from mitigating climate change?, Clim. Change Econ., 7:1640003, 1-30, 2016.

Roughgarden, T. and Schneider, S. H.: Climate change policy: Quantifying uncertainties for damages and optimal carbon taxes, Energ. Policy, 27, 415-429, 1999.

Rydge, J. and Bassi, S.: Global cooperation and understanding to accelerate climate action, in: The Global Development of Policy Regimes to Combat Climate Change, edited by: Stern, N. H., Bowen, A., and Whalley, J., World Scientific Publ. Co., Singapore, pp. 1-22, 2014.

Sahal, D.: Technical Progress: Concepts, Models, Assessment, Moscow: Finances and Statistics, 1985.

Sanderson, J.: An analysis of climate change impact and adaptation for South East Asia, PhD thesis, Centre for Strategic Economic Studies, Victoria University of Technology, Melbourne, Australia, 285 pp., 2002.

Schellnhuber, H. J., Rahmstorf, S., and Winkelmann, R.: Why the right climate target was agreed in Paris, Nat. Clim. Change, 6, 649-653, 2016.

Schneider, S. H. and Dickinson, R. E.: Climate modeling, Rev. Geophys. Space. Ge., 12, 447-493, 1974.

Schrattenholzer, L., Miketa, A., Riahi, K., and Roehrl, R. A.: Achieving a Sustainable Global Energy System: Identifying Possibilities Using Long-Term Energy Scenarios, Edward Elgar, Cheltenham, UK， \& Northampton, MA, USA, 233 pp., 2005.

Schwartz, S. E.: Heat capacity, time constant, and sensitivity of Earth's climate system, J. Geophys. Res., 112, D24S05, 1-12, 2007.

Schwartz, S.E.: Reply to comments by G. Foster et al., R. Knutti et al. and N. Scafetta on "Heat capacity, time constant, and sensitivity of Earth's climate system.” J. Geophys. Res., 113, D15105, 1-10, 2008.

Scott, C. E.: The Biogeochemical Impacts of Forests and the Implications for Climate Change Mitigation, doctoral thesis accepted by the University of Leeds, UK, Springer, Switzerland, 142 pp., 2014.

Smil, V.: Energy Transitions: History, Requirements, Prospects, Praeger, Santa Barbara, CA, 2010.

Smirnov, A.: Attainability Analysis of the DICE Model, IIASA Interim Report, IR-05-049, 2005.

Smulders, S.: Entropy, environment, and endogenous growth, Int. Tax Public Finan., 2, 319-340, 1995. 
Earth Syst. Dynam. Discuss., doi:10.5194/esd-2016-64, 2017

Manuscript under review for journal Earth Syst. Dynam.

Published: 17 January 2017

(c) Author(s) 2017. CC-BY 3.0 License.

Sohngen, B.: Forestry carbon sequestration, in: Smart Solutions to Climate Change - Comparing Costs and Benefits, edited by: Lomborg, B., Cambridge University Press, New York, NY, USA, pp. 114-132, 2010.

Solow, R. M.: A contribution to the theory of economic growth, Q. J. Econ., 70, 65-94, 1956.

Stanton, E. A., Ackerman, F., and Kartha, S.: Inside the integrated assessment models: Four issues in climate economics, Clim. Dev., 1, 166-185, 2009.

Steckel, J. C., Brecha, R. J., Jakob, M., Strefler, J., and Luderer, G.: Development without energy? Assessing future scenarios of energy consumption in developing countries, Ecol. Econ., 90, 53-67, 2013.

Steffen, W.: A truly complex and diabolical policy problem, in: The Oxford Handbook of Climate Change and Society, edited by: Dryzek, J. S., Norgaard, R. B., and Schlosberg, D., Oxford University Press, New York, NY, USA, pp. 22-36, 2012.

Stern, N. H.: The Economics of Climate Change: The Stern Review, Cambridge University Press, Cambridge and New York, 2007.

Stern, N. H.: The structure of economic modeling of the potential impacts of climate change: Grafting gross underestimation of risk onto already narrow science models, J. Econ. Lit., 51, 838-859, 2013.

Stern, N. H.: Current climate models are grossly misleading, Nature, 530, 407-409, 2016.

Sterner, T. and Coria, J.: Policy Instruments for Environmental and Natural Resource Management, 2nd Edn., RFF Press, New York, NY, USA \& London, UK, 657 pp., 2012.

Stoknes, P. E.: What We Think About When We Try Not To Think About Global Warming: Toward a New Psychology of Climate Action, Chelsea Green Publ., Vermont, VT, USA, 2015.

Swan, T. W.: Economic growth and capital accumulation, Econ. Rec., 32, 334-361, 1956.

Tol, S. J. R.: Carbon dioxide mitigation, in: Smart Solutions to Climate Change - Comparing Costs and Benefits, edited by: Lomborg, B., Cambridge University Press, New York, NY, USA, pp. 74-105, 2010.

Tol, S. J. R. and Fankhauser, S.: On the representation of impact in integrated assessment models of climate change, Environ. Model. Assess., 3, 63-74, 1998.

Traeger, C. P.: A 4-Stated DICE: Quantitatively addressing uncertainty effects in climate change, Environ. Resource Econ., 59:1-37, 2014.

UNFCCC: Copenhagen Accord, United Nations, New York, NY, US A, 2009.

UNFCCC: United Nations Framework Convention on Climate Change, Adoption of the Paris Agreement: Proposal by the President, Report No. FCCC/CP/2015/L.9/Rev.1, 2015, Geneva, Switzerland, 32 pp., 2015.

Uzawa, H.: Economic Theory and Global Warming, Cambridge University Press, New York, NY, USA, 293 pp., 2003.

Van Den Bergh, J. C. J. M.: Safe climate policy is affordable: 12 reasons, in: Climate Change Mitigation: Greenhouse Gas Reduction and Biochemicals, edited by: Albanese, J. A. F. and Ruiz, M. P., Apple Academic Press, Oakville, Canada, pp. 299-357, 2015

Van Vuuren, D. P., Eickhout, B., Lucas, P. L., and Den Elzen, M. G. J.: Long-term multi-gas scenarios to stabilize radiative forcing - exploring costs and benefits within an integrated assessment framework, Energ. J., 27, 201-233, 2006a.

Van Vuuren, D. P., Riahi, K., Moss, R., Edmonds, J., Thomson, A., Nakićenović, N., Kram, T., Berkhout, F., Swart, R., Janetos, A., Rose, S. K., and Arnell, N.: A proposal for a new scenario framework to support research and assessment in different climate research communities, Global Environ. Change, 22, 21-35, 2012.

Van Vuuren, D. P., Den Elzen, M. G. J., Lucas, P. L., Eickhout, B., Strengers, B. J., Van Ruijven, B., Berk, M. M., De Vries, H. J. M., Hoogwijk, M., Meinshausen, M., Wonink, S. J., Van den Houdt, R., and Oostenrijk, R.: Stabilizing greenhouse gas concentrations at low levels: An assessment of options and costs, Report 
Earth Syst. Dynam. Discuss., doi:10.5194/esd-2016-64, 2017

Manuscript under review for journal Earth Syst. Dynam.

Published: 17 January 2017

(c) Author(s) 2017. CC-BY 3.0 License.

500114002/2006 Netherlands Environmental Assessment Agency (MNP), Bilthoven, the Netherlands, 273 pp., 2006b.

Wagner, G. and Weitzman, M. L.: Climate Shock: The Economic Consequences of a Hotter Planet, Princeton University Press, Princeton, USA, \& Oxford, UK, 265 pp., 2015.

Wasdell, D.: Climate dynamics: Facing the harsh realities of now - climate sensitivity, target temperature and the carbon budget: Guidelines for strategic action, Apollo-Gaia Project, Unit for Research into Changing Institutions, London, UK, 2015.

Weber, M., Barth, V., and Hasselmann, K.: A multi-actor dynamic integrated assessment model (MADIAM) of induced technological change and sustainable economic growth, Ecol. Econ., 54, 306-327, 2005.

Wigley, T. M. L.: A simple inverse carbon cycle model, Global Biogeochem. Cy., 5, 373-382, 1991.

Wise, M., Calvin, K., Thomson, A., Clarke, L., Bond-Lamberty, B., Sands, R., Smith, S. J., Janetos, A., and Edmonds, J.: Implications of limiting $\mathrm{CO}_{2}$ concentrations for land use and energy, Science, 324, 11831186, 2009.

Wouter Botzen, W. and Van den Bergh, J. C. J. M.: How sensitive is Nordhaus to Weitzman? Climate policy in DICE with an alternative damage function, Econ Lett., 117, 372-374, 2012.

Xu, J., Yao, L., and Lu, Y.: Innovative Approaches Towards Low Carbon Economics: Regional Development Cybernetics, Springer, Berlin, Heidelberg, Germany, 453 pp., 2014.

Zaddach, J. O.: Climate Policy Under Intergenerational Discounting: An Application of the Dynamic Integrated Climate-Economy Model, master thesis Albert-Ludwigs-University of Freiburg, 2015 u.d.t., Springer, Fachmedien Wiesbaden, Germany, 67 pp., 2016. 
Earth Syst. Dynam. Discuss., doi:10.5194/esd-2016-64, 2017

Manuscript under review for journal Earth Syst. Dynam.

Published: 17 January 2017

(c) Author(s) 2017. CC-BY 3.0 License.

Table 1. List of variables and parameters and their values used.

\begin{tabular}{|c|c|c|c|c|}
\hline Symbol & Meaning & Value & Units & Source \\
\hline \multicolumn{5}{|c|}{ Independent variables } \\
\hline$K$ & Per capita physical capital & & $10^{4} \mathrm{USD}_{1990}$ & \\
\hline$H$ & Per capita human capital & & $10^{4} \mathrm{USD}_{1990}$ & \\
\hline$T$ & Average global surface temperatures & & Kelvin $(\mathrm{K})$ & \\
\hline$C$ & Atmospheric $\mathrm{CO}_{2}$ concentration & & $\mathrm{GtC}$ & \\
\hline$E_{\mathrm{Y}}$ & Industrial $\mathrm{CO}_{2}$ emissions & & $\mathrm{GtC}_{\mathrm{yr}}{ }^{-1}$ & \\
\hline \multicolumn{5}{|c|}{ Initial (1990) values for independent variables } \\
\hline$k_{0}$ & $\begin{array}{l}\text { Per capita physical capital-human } \\
\text { capital ratio } K_{0} / H_{0}\end{array}$ & 8.1 & Ratio & Erk et al. (1998) \\
\hline$K_{0}$ & & 0.8344 & $10^{4} \mathrm{USD}_{1990}$ & $\begin{array}{l}\text { Nordhaus and Boyer } \\
\text { (2000) }\end{array}$ \\
\hline$H_{0}$ & & 0.1039 & $10^{4} \mathrm{USD}_{1990}$ & $K_{0} / k_{0}$ \\
\hline$T_{0}$ & & 287.77 & Kelvin $(\mathrm{K})$ & $\begin{array}{l}\text { Dong et al. }(2013 \text {, } \\
\text { Fig. 3.22) }\end{array}$ \\
\hline$C_{0}$ & & 735 & $\mathrm{GtC}$ & $\begin{array}{l}\text { Nordhaus and Boyer } \\
\text { (2000) }\end{array}$ \\
\hline$E_{\mathrm{Y} 0}$ & & 6 & $\mathrm{GtC}_{\mathrm{yr}}{ }^{-1}$ & Lenton (2000) \\
\hline \multicolumn{5}{|c|}{ Parameters and other symbols } \\
\hline \multicolumn{5}{|c|}{ Economy module } \\
\hline$n$ & Population growth rate & & $\% \mathrm{yr}^{-1}$ & $\begin{array}{l}\text { Nordhaus and Sztorc } \\
\text { (2013) }\end{array}$ \\
\hline$L$ & Human population & & Millions & \\
\hline$L_{0}$ & 1990 world population & 5632.7 & Millions & $\begin{array}{l}\text { Nordhaus and Boyer } \\
(2000)\end{array}$ \\
\hline$n_{0}$ & 1990 population growth rate & 1.57 & $\% \mathrm{yr}^{-1}$ & $\begin{array}{l}\text { Nordhaus and Boyer } \\
\text { (2000) }\end{array}$ \\
\hline$A$ & Total factor productivity & 2.9 & & $\begin{array}{l}\text { Greiner and Semmler } \\
\text { (2008) }\end{array}$ \\
\hline$c$ & Consumption share & 80 & $\% \mathrm{yr}^{-1}$ & $\begin{array}{l}\text { Greiner and Semmler } \\
\text { (2008) }\end{array}$ \\
\hline$\varphi$ & External effect coefficient & 0.1235 & & \\
\hline$\delta_{\mathrm{K}}$ & Depreciation rate of $K$ & 7.5 & $\% \mathrm{yr}^{-1}$ & $\begin{array}{l}\text { Greiner and Semmler } \\
\text { (2008) }\end{array}$ \\
\hline$\delta_{\mathrm{H}}$ & Depreciation rate of $H$ & 7.2 & $\% \mathrm{yr}^{-1}$ & \\
\hline$\delta_{\mathrm{n}}$ & Decline rate of $n$ & 2.22 & $\% \mathrm{yr}^{-1}$ & $\begin{array}{l}\text { Nordhaus and Boyer } \\
(2000)\end{array}$ \\
\hline$\alpha$ & Physical capital share & 0.35 & & Gollin (2002) \\
\hline$\tau$ & Tax rate & 20 & $\% \mathrm{yr}^{-1}$ & $\begin{array}{l}\text { Greiner and Semmler } \\
\text { (2008) }\end{array}$ \\
\hline$\tau_{\mathrm{b}}$ & Abatement share & $\begin{array}{l}0 ; 0.075 ; 0.11 ; \\
0.145\end{array}$ & Ratio & \\
\hline \multicolumn{5}{|c|}{ Damage function } \\
\hline \multicolumn{2}{|c|}{$m_{1}$} & 0.0067 & & $\begin{array}{l}\text { Roughgarden and } \\
\text { Schneider (1999) }\end{array}$ \\
\hline$\chi$ & & 2.43 & & \\
\hline \multicolumn{5}{|c|}{ Climate module (carbon cycle \& surface temperature) } \\
\hline$\beta_{2}$ & $\begin{array}{l}\text { Part of } \mathrm{CO}_{2} \text { emissions taken up by } \\
\text { oceans and do not enter the atmosphere }\end{array}$ & 0.49 & & IPCC (2001, p. 39) \\
\hline$\mu_{o}$ & $\begin{array}{l}\text { Rate of } \mathrm{CO}_{2} \text { absorption from the } \\
\text { atmosphere into the ocean }\end{array}$ & 0.0083 & & Nordhaus (1994a) \\
\hline$\hat{C}$ & Pre-industrial $\mathrm{CO}_{2}$ concentration & 596.4 & $\mathrm{GtC}$ & Wigley (1991) \\
\hline$e_{\mathrm{c}}$ & Energy intensity & & $\operatorname{TRF}\left(\text { USD } 10^{3} \text { of } \bar{Y}\right)^{-1}$ & Akaev (2015) \\
\hline$c_{\mathrm{c}}$ & Carbon intensity of energy & & $\mathrm{tC} \mathrm{TRF}^{-1}$ & Akaev (2015) \\
\hline$g_{\mathrm{ec}}$ & Growth rate of $e_{\mathrm{c}}$ & & & \\
\hline$g_{\mathrm{cc}}$ & Growth rate of $c_{\mathrm{c}}$ & & & \\
\hline$\sigma$ & Carbon intensity & & $\mathrm{tC}\left(\mathrm{USD} 10^{3} \text { of } \bar{Y}\right)^{-1}$ & Akaev (2015) \\
\hline$g_{\sigma}$ & Rate of decline of $\sigma$ & & & \\
\hline$\sigma_{0}$ & 1990 level $\sigma$ & 0.274 & $\operatorname{tC}\left(\operatorname{USD} 10^{3} \text { of } \bar{Y}\right)^{-1}$ & $\begin{array}{l}\text { Nordhaus and Boyer } \\
(2000)\end{array}$ \\
\hline$\psi_{0}$ & & 0.042 & & Akaev (2015) \\
\hline$\alpha_{\tau}$ & Abatement efficiency & 1.8 & & \\
\hline$r$ & & 0.05 & & Akaev (2015) \\
\hline
\end{tabular}


Earth Syst. Dynam. Discuss., doi:10.5194/esd-2016-64, 2017

Manuscript under review for journal Earth Syst. Dynam.

Published: 17 January 2017

(c) Author(s) 2017. CC-BY 3.0 License.
Earth System
Dynamics

Discussions

\begin{tabular}{lllll}
$c_{-\infty}$ & $\mathrm{C}_{\mathrm{c}}$ used before 1990 & 0.1671 & $\mathrm{TC} \mathrm{TRF}^{-1}$ & \\
$a_{\mathrm{c}}$ & & 0.169 & & Akaev (2015) \\
$c_{\mathrm{h}}$ & Earth specific heat capacity & 16.7 & $\mathrm{~W} \mathrm{~m}^{-2} \mathrm{~K}^{-1}$ & Schwartz (2008) \\
$\alpha_{\mathrm{T}}$ & Planetary/Surface albedo & 0.3 & & Greiner (2015) \\
$\varepsilon$ & Emissivity & 0.95 & & Greiner (2015) \\
$\sigma_{\mathrm{T}}$ & Stefan-Boltzmann constant & $5.67 \times 10^{-8}$ & $\mathrm{~W} \mathrm{~m}^{-2} \mathrm{~K}^{-4}$ & Greiner (2015) \\
$\tau_{\mathrm{a}}$ & Infrared transmissivity & 0.6526 & & McGuffie and \\
& & & & Henderson-Sellers \\
$\mathrm{Q}$ & Solar constant & 1366 & $\mathrm{~W} \mathrm{~m}^{-2}$ & (2005) \\
$\xi$ & $T$ rise absorbed by the oceans & Greiner (2004) \\
$\beta_{1}$ & Feedback effect & 0.23 & & (2008) \\
$\hat{T}$ & Pre-industrial $T$ & 3.3 & & Greiner (2015) \\
& & 287.17 & $\mathrm{~K}$ & Dong et al. (2013, \\
\hline
\end{tabular}

Table 2. Target values of key variables for our policy scenarios at year 2100, with $\chi=2.43$.

\begin{tabular}{|c|c|c|c|c|c|}
\hline $\begin{array}{l}\text { Abatement } \\
\text { share } \\
\tau_{\mathrm{b}}\end{array}$ & $\begin{array}{l}\text { Emissions } \\
E_{\mathrm{Y}} \\
\left(\mathrm{GtC} \mathrm{yr}^{-1}\right)\end{array}$ & $\begin{array}{l}\mathrm{CO}_{2} \\
C / \hat{C}\end{array}$ & $\begin{array}{l}\text { SAT deviation from } \\
\text { pre-industrial } \\
T-\hat{T}\left({ }^{\circ} \mathrm{C}\right)\end{array}$ & $\begin{array}{l}\text { Damages } \\
(\% Y)\end{array}$ & $\begin{array}{l}\text { Per capita GDP } \\
\text { growth } g_{\mathrm{Y}}\left(\% \mathrm{yr}^{-1}\right)\end{array}$ \\
\hline 0 & 29.3 & 3.1 & 5.2 & 26.9 & 1.1 \\
\hline 0.075 & 11.8 & 2.1 & 3.4 & 11.6 & 2.1 \\
\hline 0.11 & 5.9 & 1.7 & 2.6 & 6.6 & 2.2 \\
\hline 0.145 & 2.5 & 1.5 & 2.0 & 3.5 & 2.0 \\
\hline
\end{tabular}

5

Table 3. Per capita abatement costs and damage costs at year 2100, with $\chi=2.43$.

\begin{tabular}{llll}
\hline Abatement share $\tau_{\mathrm{b}}$ & $\begin{array}{l}\text { \% emissions }\left(E_{\mathrm{Y}}\right) \text { reduction from } \\
\text { BAU }\end{array}$ & $\begin{array}{l}\text { Per capita abatement costs } \\
(\% Y)\end{array}$ & $\begin{array}{l}\text { Per capita damage costs } \\
(\% Y)\end{array}$ \\
\hline 0 & 0 & 0 & 26.9 \\
0.075 & 60 & 1.5 & 11.6 \\
0.11 & 80 & 2.2 & 6.6 \\
0.145 & 92 & 2.9 & 3.5 \\
\hline
\end{tabular}

Table 4. Comparison between global results of alternative policies.

\begin{tabular}{|c|c|c|c|c|c|c|c|}
\hline \multicolumn{8}{|c|}{ Global industrial $\mathrm{CO}_{2}$ emissions $\left(\mathrm{GtC} \mathrm{yr}^{-1}\right)$} \\
\hline Policy Scenario & 1995 & 2005 & 2010 & 2020 & 2030 & 2050 & 2100 \\
\hline CoCEB model: $\tau_{b}=0$ & 7.1 & 10.8 & 13.2 & 19.3 & 27.0 & 43.4 & 29.3 \\
\hline CoCEB model: $\tau_{b}=0.075$ & 6.8 & 9.2 & 10.6 & 13.8 & 17.0 & 21.6 & 11.8 \\
\hline CoCEB model: $\tau_{b}=0.11$ & 6.7 & 8.6 & 9.6 & 11.7 & 13.5 & 14.7 & 5.9 \\
\hline RCP8.5 (Riahi et al., 2007) & - & 8 & 8.9 & 11.5 & 13.8 & 20.2 & 28.7 \\
\hline RCP6.0 (Hijioka et al., 2008) & - & 8 & 8.5 & 9 & 10 & 13 & 13.8 \\
\hline RCP4.5 (Wise et al., 2009) & - & 8 & 8.6 & 9.9 & 11 & 11 & 4.2 \\
\hline \multicolumn{8}{|c|}{ Global atmospheric $\mathrm{CO}_{2}$ concentration $(\mathrm{GtC})$} \\
\hline & 1995 & 2010 & 2020 & 2030 & 2050 & 2075 & 2100 \\
\hline CoCEB model: $\tau_{b}=0$ & 743 & 793 & 852 & 939 & 1206 & 1612 & 1842 \\
\hline CoCEB model: $\tau_{b}=0.075$ & 743 & 785 & 826 & 880 & 1014 & 1168 & 1231 \\
\hline CoCEB model: $\tau_{b}=0.11$ & 743 & 781 & 816 & 858 & 948 & 1027 & 1037 \\
\hline RCP8.5 (Riahi et al., 2007) & - & 829 & 886 & 956 & 1151 & 1529 & 1993 \\
\hline RCP6.0 (Hijioka et al., 2008) & - & 829 & 872 & 914 & 1017 & 1218 & 1427 \\
\hline RCP4.5 (Wise et al., 2009) & - & 829 & 875 & 927 & 1036 & 1124 & 1147 \\
\hline
\end{tabular}

10 
Earth Syst. Dynam. Discuss., doi:10.5194/esd-2016-64, 2017

Manuscript under review for journal Earth Syst. Dynam.

Published: 17 January 2017

(c) Author(s) 2017. CC-BY 3.0 License.

Table 5. Policy scenario values at year 2100 with $\alpha_{\tau}=1.8$, varying $m_{1}$, and $\chi$.

\begin{tabular}{|c|c|c|c|c|c|c|c|}
\hline & & $\begin{array}{l}\text { Abatement } \\
\text { share } \tau_{\mathrm{b}}\end{array}$ & $\begin{array}{l}\text { Emissions } \\
E_{\mathrm{Y}} \\
\left(\mathrm{GtC} \mathrm{yr}^{-1}\right)\end{array}$ & $\begin{array}{l}\mathrm{CO}_{2}, \\
C / \hat{C}\end{array}$ & $\begin{array}{l}\text { Deviation from } \\
\text { pre-industrial, } \\
T-\hat{T}\left({ }^{\circ} \mathrm{C}\right)\end{array}$ & $\begin{array}{l}\text { Damages } \\
(\% Y)\end{array}$ & $\begin{array}{l}\text { GDP } \\
\text { growth } g_{\mathrm{Y}} \\
\left(\% \mathrm{yr}^{-1}\right)\end{array}$ \\
\hline$m_{1}=0.034$ & $\chi=2.34$ & 0 & 50.8 & 3.7 & 5.9 & 20.3 & 1.8 \\
\hline \multirow{3}{*}{$(-50 \%)$} & & 0.075 & 16.0 & 2.2 & 3.7 & 7.3 & 2.5 \\
\hline & & 0.11 & 7.3 & 1.8 & 2.8 & 3.8 & 2.4 \\
\hline & & 0.145 & 2.8 & 1.5 & 2.1 & 1.9 & 2.1 \\
\hline$m_{1}=0.01$ & & 0 & 20.4 & 2.8 & 4.7 & 30.3 & 0.7 \\
\hline \multirow{3}{*}{$(+50 \%)$} & & 0.0175 & 9.3 & 2.0 & 3.2 & 14.4 & 1.8 \\
\hline & & 0.11 & 5.0 & 1.7 & 2.5 & 8.6 & 2 \\
\hline & & 0.145 & 2.2 & 1.5 & 1.9 & 4.8 & 1.9 \\
\hline$\chi=1.215$ & $m_{1}=0.0067$ & 0 & 99.6 & 4.5 & 6.7 & 6.3 & 3.6 \\
\hline \multirow[t]{3}{*}{$(-50 \%)$} & & 0.075 & 19.1 & 2.3 & 3.8 & 3.3 & 3.0 \\
\hline & & 0.11 & 7.8 & 1.8 & 2.8 & 2.3 & 2.6 \\
\hline & & 0.145 & 2.9 & 1.5 & 2.1 & 1.6 & 2.2 \\
\hline$\chi=3.645$ & & 0 & 6.0 & 2.1 & 3.6 & 41.6 & -0.2 \\
\hline \multirow{3}{*}{$(+50 \%)$} & & 0.075 & 4.9 & 1.8 & 2.8 & 22.9 & 1.0 \\
\hline & & 0.11 & 3.5 & 1.6 & 2.4 & 13.5 & 1.6 \\
\hline & & 0.145 & 1.9 & 1.5 & 1.9 & 6.6 & 1.8 \\
\hline
\end{tabular}

5

Table 6. Effect of varying $\alpha_{\tau}$ by year 2100; all other parameter values as in Table 1.

\begin{tabular}{llllll}
\hline & $\begin{array}{l}\text { Abatement } \\
\text { share } \tau_{\mathrm{b}}\end{array}$ & $\begin{array}{l}\text { \% reduction of } \\
\text { emissions }\left(E_{\mathrm{Y}}\right) \\
\text { from BAU }\end{array}$ & $\begin{array}{l}\text { Per capita abatement } \\
\text { costs } \\
(\% Y)\end{array}$ & $\begin{array}{l}\text { Per capita } \\
\text { damage costs } \\
(\% Y)\end{array}$ & $\begin{array}{l}\text { GDP } \\
\text { growth } g_{\mathrm{Y}} \\
\left(\% \mathrm{yr}^{-1}\right)\end{array}$ \\
\hline Abatement & 0 & 0 & 0 & 26.9 & 1.1 \\
efficiency $=0.9$ & 0.075 & 48 & 1.5 & 13.6 & 1.8 \\
$(-50 \%)$ & 0.11 & 67 & 2.2 & 8.8 & 1.9 \\
& 0.145 & 81 & 2.9 & 5.5 & 1.8 \\
\hline Abatement & 0 & 0 & 0 & 26.9 & 1.1 \\
efficiency $=2.7$ & 0.075 & 71 & 2.5 & 9.4 & 2.3 \\
$(+50 \%)$ & 0.11 & 90 & 2.9 & 4.4 & 2.4 \\
& 0.145 & 98 & & 1.9 & 2.1 \\
\hline
\end{tabular}

10 
Earth Syst. Dynam. Discuss., doi:10.5194/esd-2016-64, 2017

Manuscript under review for journal Earth Syst. Dynam.

Published: 17 January 2017

(c) Author(s) 2017. CC-BY 3.0 License.

(c) (i) (a) $\mathrm{CO}_{2}$ emissions $\left(\mathrm{GtCyr}^{-1}\right)$

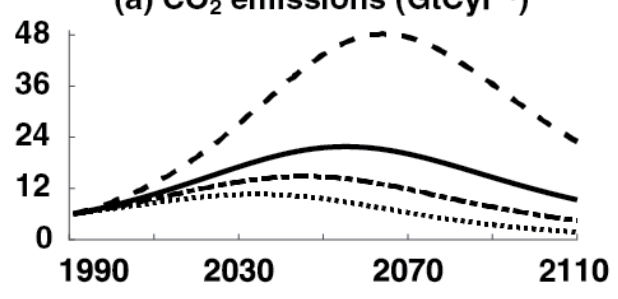

(c) Temperature Deviation $\left({ }^{\circ} \mathrm{C}\right)$

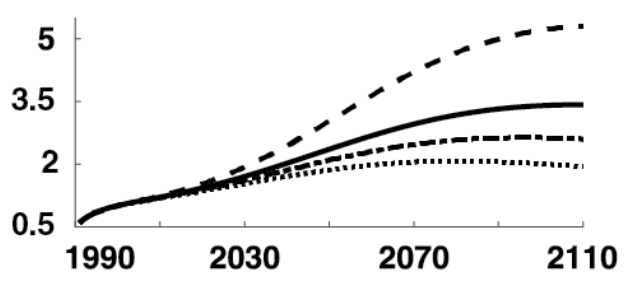

(e) GDP growth $\left(\% \mathrm{yr}^{-1}\right)$

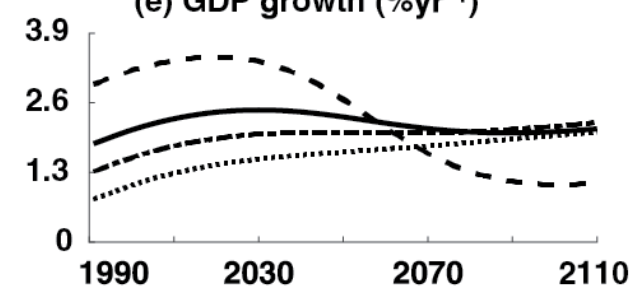

(b) Atmospheric $\mathrm{CO}_{2}$ (GtC)

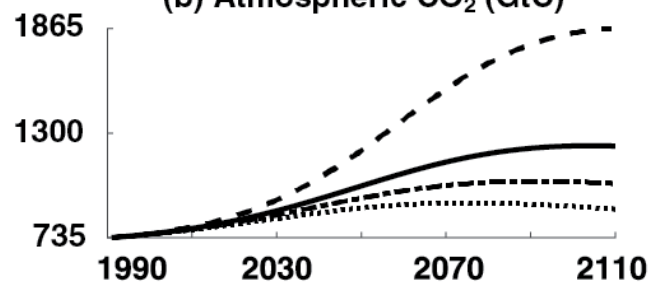

(d) Damages (\% of $Y$ )

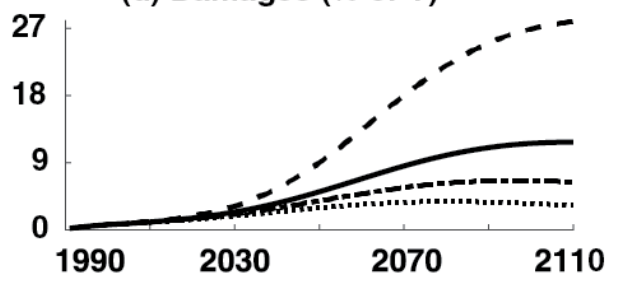

(f) $\mathrm{CO}_{2}$ emissions growth $\left(\% \mathrm{yr}^{-1}\right)$

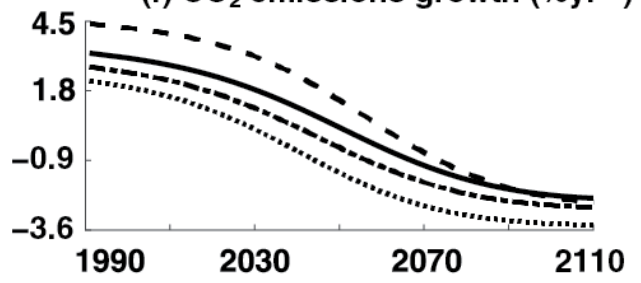

$$
--\tau_{b}=0 \quad-\tau_{b}=0.075 \quad \cdots-\tau_{b}=0.11 \quad \cdots \cdots \cdot \tau_{b}=0.145
$$

Figure 1. Evolution of several CoCEB model variables in time, for abatement shares $\tau_{\mathrm{b}}$ that range from 0.0 (no abatement) to 0.145; see legend for curves, with $\tau_{b}=0$ - dashed, $\tau_{b}=0.075-$ solid, $\tau_{b}=0.11-$ dash-dotted, and $\tau_{b}=0.145$ - dotted. 
Earth Syst. Dynam. Discuss., doi:10.5194/esd-2016-64, 2017

Manuscript under review for journal Earth Syst. Dynam.

Published: 17 January 2017

(c) Author(s) 2017. CC-BY 3.0 License.

(c) (i)

\section{Earth System \\ Dynamics}

Discussions (a) GDP growth $\left(\% \mathrm{yr}^{-1}\right) ; \mathrm{m}_{1}=0.0034$

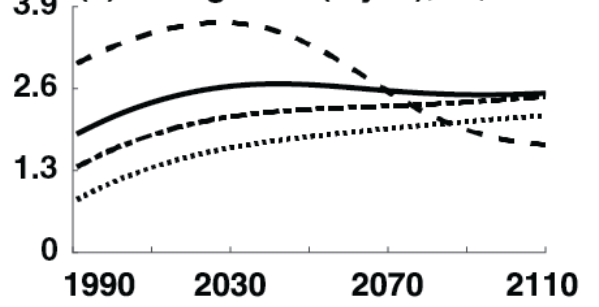

(c) GDP growth $\left(\% \mathrm{yr}^{-1}\right) ; \chi=1.215$

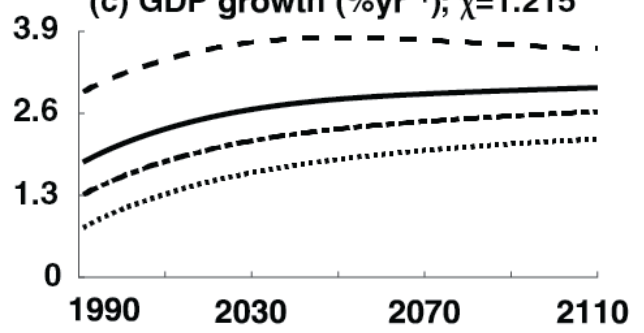

(b) GDP growth $\left(\% \mathrm{yr}^{-1}\right) ; \mathrm{m}_{1}=0.01$

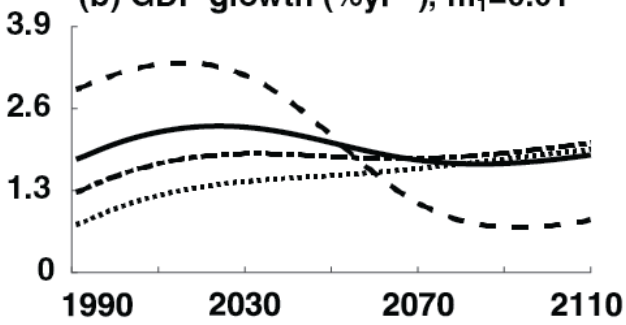

(d) GDP growth $\left(\% \mathrm{yr}^{-1}\right) ; \chi=3.645$

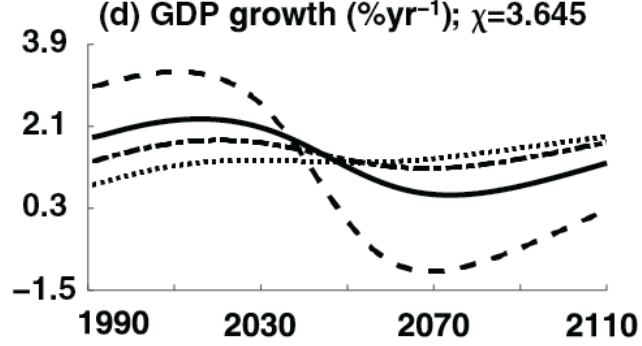

Figure 2. Per capita GDP growth over time as a function of abatement share values $\tau_{\mathrm{b}}$ between 0.0 and 0.145 ; see legend for curve identification, while $\alpha_{\tau}=1.8$. Panels (a, b) the coefficient $m_{1}$ is larger or smaller by $50 \%$ than the value in Tables 1-4; (c, d) same for the exponent $\chi$. 